\title{
Reassessing Concurrent Tribal-State-Federal Criminal Jurisdiction in Kansas
}

\author{
John J. Francis, Stacy L. Leeds, ${ }^{* *}$ Aliza Organick, ${ }^{* * *}$ \& Jelani Jefferson \\ Exum $^{* * * *}$
}

\section{INTRODUCTION}

Federal Indian Law is frequently described as a jurisdictional quagmire. ${ }^{1}$ Depending on the unique history of a given tribe, the extent to which the tribe has retained a territorial boundary or contiguous landbase, and depending on a tribe's geographic location, a different mix of exclusive or concurrent tribal, state, federal jurisdiction will result. ${ }^{2}$

* John J. Francis, Professor of Law, Washburn University School of Law; Director, Washburn Law Clinic. Professor Francis began his career with the New York City Legal Aid Society, Criminal Defense Division, as a trial attorney. He has been a clinical legal educator for seventeen years. As a professor in Washburn's Law Clinic, among other things, Professor Francis supervises law students handling criminal defense matters in the Prairie Band Potawatomi Nation District Court.

I thank my co-authors for their tremendous insight and hard work on this project. I commend Michael Duma, who located a treasure trove of historical documents, shedding new light on the history behind the Kansas Act. I also thank Andrew Evans, Government Documents Librarian at Washburn Law, who unearthed documents in the National Archives from Prairie Band Potawatomi Nation which had been left out of the legislative history of the Kansas Act. Finally, I thank my wife Irene and my sons Punleu and Chuan for their encouragement and inspiration.

${ }^{* *}$ Stacy L. Leeds, Dean and Professor of Law, University of Arkansas. Dean Leeds also served as Chief Administrative District Court Judge for the Prairie Band Potawatomi from 2008 to 2011 and as Special District Court Judge for the Kickapoo Tribe in Kansas in 2011.

${ }_{* * * *}^{*}$ Aliza Gail Organick, Professor of Law, Washburn University School of Law, citizen of the Diné Nation, born to the Tséníjíkiní (Cliff Dweller) Clan. In 2004, Professor Organick founded the Tribal and State Court Practice Clinic at Washburn University School of Law. She currently serves on the Board of Directors of the National Native Bar Association and on the Executive Committee for the AALS Section on Tribal Nations and Indigenous Peoples. In addition to teaching in the Clinical Program at Washburn, Professor Organick also teaches classes on the International Law of Indigenous Peoples, Comparative Law, and Tribal Court Practice.

${ }^{* * * * *}$ Jelani Jefferson Exum, Associate Professor of Law, University of Toledo College of Law. Professor Exum researches and writes in the area of Federal Sentencing and teaches issues pertaining to Federal Indian Policy in her course on Race and American Law.

1. Confederated Bands \& Tribes of Yakima Indian Nation v. Washington, 550 F.2d 443, 452 (9th Cir. 1997); see also Duro v. Reina, 495 U.S. 676, 680 n.1 (1990), superseded by statute on other grounds, Department of Defense Appropriations Act, Pub. L. No. 101-511, 104 Stat. 1856 (1990).

2. Okla. Tax Comm'n v. Sac \& Fox Nation, 508 U.S. 114, 125 (1993); White Mountain Apache Tribe v. Bracker, 448 U.S. 136, 145 (1980); Moe v. Confederated Salish \& Kootenai Tribes 
Moreover, the practical realities on the ground often result in one sovereign entity exercising more or less power than the law on the books might otherwise suggest. ${ }^{3}$

In the criminal law context, tribal-state-federal jurisdiction generally rests on the three premises: (1) tribes retain inherent authority to prosecute American Indians, regardless of an individual's precise tribal affiliation; (2) a mix of federal statutes authorize federal prosecution of some crimes that occur within Indian country; and (3) states lack authority to prosecute Indian country crimes absent express federal authorization of state authority. ${ }^{4}$

These foundations of Federal Indian law have resulted in the understanding that Indian country crimes are a matter of tribal and federal concern. ${ }^{5}$ States only expend resources and exercise criminal jurisdiction over Indian country crimes when a state-specific allocation of jurisdiction to the state warrants state involvement. ${ }^{6}$ States, particularly in this current economic downtown, have little incentive to expend limited resources on criminal prosecutions inside Indian country-and conceptually outside the traditional definition of state authority-unless there is a jurisdictional gap. Gaps have historically occurred when, as a practical reality, neither the federal government, nor the tribal government is actively providing law enforcement and consistent prosecution. ${ }^{7}$

The history of tribal-state-federal relations within the state of Kansas has produced a unique state-specific scenario for apportioning criminal jurisdiction between the three sovereigns. Kansas is unusual among states, where an individual American Indian committing a single crime within Indian country ${ }^{8}$ may face prosecution by all three

of Flathead Reservation, 425 U.S. 463, 480-81 (1976).

3. See, e.g., Negonsott v. Samuels, 507 U.S. 99, 106-07 (1993).

4. See United States v. Kagama, 118 U.S. 375, 379-80 (1886); see also 25 U.S.C. § 1301(2) (2006) (confirming that tribes have the authority to regulate activities of Indians in Indian country, regardless of membership status).

5. Kagama, 118 U.S. at 379; Ex parte Crow Dog, 109 U.S. 556, 571-72 (1883); Worcester v. Georgia, 31 U.S. 515, 539-40 (1832), abrogated on other grounds by Bracker, 448 U.S. 136.

6. See Okla. Tax Comm'n, 508 U.S. at 125; In re Kan. Indians, 72 U.S. 737, 760-61 (1866); Worcester, 31 U.S. at 593.

7. See, e.g., Negonsott, 507 U.S. at 106-07 (discussing that the legislative history of the Kansas Act noted that, in practice, Kansas exercised jurisdiction over all offences committed on Indian reservations involving Indians because such offenses otherwise went unpunished).

8. 18 U.S.C. § 1151 (2006) (defining "Indian country” as (a) all land within the limits of any reservation, (b) all dependent Indian communities within the borders of the United States, and (c) all Indian allotments, the Indian titles to which have not been extinguished). 
sovereigns: the United States, ${ }^{9}$ the state of Kansas, ${ }^{10}$ and one of the four federally recognized tribes located within the exterior boundaries of the state of Kansas ${ }^{11}$ - Prairie Band Potawatomi, Kickapoo Tribes in Kansas, Sac and Fox Nation, or the Iowa Tribe of Kansas and Missouri. ${ }^{12}$

Although the unique Kansas scenario came about because of a perceived jurisdictional gap in the 1930s, the modern realities of tribalstate-federal relations in Kansas, particularly in light of the development and growth of tribal courts, no longer support the continued need for multijurisdictional criminal coverage. As such, this Article questions the continued viability of the Kansas Act federal legislation, which extended Indian country criminal jurisdiction to the state of Kansas, while leaving unimpaired preexisting tribal and federal jurisdiction over the same offenses. This Article concludes with recommendations for legislative reform and the consideration of intergovernmental agreements with an eye toward providing a solution that respects modern policies of tribal self-determination, protects the financial resources and judicial economy of state and tribal courts, and protects the rights of defendants who may be subject to multiple prosecutions for the same offense.

\section{HISTORY OF CRIMINAL JURISDICTION IN INDIAN COUNTRY}

At the time of Kansas' admission to the federal union in 1861, tribes throughout the United States exercised criminal jurisdiction within their territories. $^{13}$ Although federal law first purported to extend federal jurisdiction over non-Indians committing offenses against Indians in the

9. General Crimes Act, 18 U.S.C. § 1152 (2006); Major Crimes Act, 18 U.S.C. § 1153 (2006).

10. Kansas Act, 18 U.S.C. § 3243 (2006) (conferring jurisdiction on the state of Kansas over state offenses committed by or against Indians on Indian reservations located within the State of Kansas).

11. United States v. Lara, 541 U.S. 193, 199 (2004) (recognizing that congress granted each tribe "the inherent" tribal power (not delegated federal power) to prosecute nonmember Indians for misdemeanors").

12. Julene L. Miller, Tribal v. State Government: Drawing the Lines, J. KAN. B. Ass'N., Jan. 2001, at 24, 24 n.1.

13. Worcester v. Georgia, 31 U.S. 515, 559-61 (1832) ("The Indian nations had always been considered as distinct, independent political communities... recognizing their title to selfgovernment.”), abrogated on other grounds by White Mountain Apache Tribe v. Bracker, 448 U.S. 136 (1980); see, e.g., SIDNEY L. HARRING, CROW DOG'S CASE: AMERICAN INDIAN SOVEREIGNTY, TRIBAL LAW, AND UNITED STATES LAW IN THE NinETEENTH CENTURY 1 (1994); K.N. LLEWELLYN \& E. Adamson hoebel, The Cheyenne Way: Conflict and Case LaW in Primitive JURISPRUDENCE 67-98 (1941) (describing the origin and rise of tribal law as centering on cases of intratribal homicide); Robert Yazzie, "Life Comes From It": Navajo Justice Concepts, 24 N.M. L. REV. 175, 177 (1994) (explaining that the first modern Navajo courts were introduced in 1892). 
$1790 s,{ }^{14}$ the federal statutory scheme as it existed in 1861, expressly disavowed federal criminal jurisdiction over Indian-on-Indian crimes within Indian country. ${ }^{15}$ It was also well-established that states had no authority for extending their laws into tribal territories. ${ }^{16}$ Even as late as 1883, the United States Supreme Court validated the continuance of exclusive tribal jurisdiction over intratribal crimes, despite attempts by federal officials to extend federal criminal laws into Indian country. ${ }^{17}$

In 1885, with the passage of the Major Crimes Act (MCA), ${ }^{18}$ Congress extended federal criminal jurisdiction into Indian country, providing for the first time federal prosecutorial power over Indians independent of whether the victim of the crime be Indian or non-Indian. ${ }^{19}$ The MCA provided for federal prosecution over certain crimes but did not purport to authorize state jurisdiction. ${ }^{20}$ Instead, the passage of the MCA in concert with the previous federal statutory scheme of federal jurisdiction over interracial crimes set up a system whereby Indian country crimes would be prosecuted by federal or tribal officials, or both. Numerous cases within the federal system uphold the right of the tribe and the right of the federal government to prosecute an individual, without double jeopardy concerns, based on the fact that both sovereigns are exercising independent sovereign powers. ${ }^{21}$

During this time period, the only instances in which states were authorized to exercise criminal jurisdiction inside Indian country were those offenses in which both the perpetrator and the victim were nonIndian. $^{22}$ State jurisdiction in those instances was judicially sanctioned

14. Trade and Intercourse Act of 1790 , ch. 33 , § 5, 1 Stat. 137, 138; Trade and Intercourse Act of 1799, ch. 46, § 4, 1 Stat. 743, 744-45; Trade and Intercourse Act of 1802, ch. 13, § 4, 2 Stat. 139, 141.

15. General Crimes Act, ch. 92, 3 Stat. 383 (1817) (codified as amended at 18 U.S.C. § 1152 (2006)).

16. Worcester, 31 U.S. at 561.

17. Ex Parte Crow Dog, 109 U.S. 556, 570-72 (1883). See generally Robert N. Clinton, Development of Criminal Jurisdiction over Indian Lands: The Historical Perspective, 17 ARIZ. L. REV. 951 (1975).

18. Major Crimes Act, ch. 342, 23 Stat. 385 (1885) (codified as amended at 18 U.S.C. § 1153 (2006)).

19. Id.

20. Id.

21. United States v. Wheeler, 435 U.S. 313, 330-31 (1978) (stating that the tribe and federal government both retain the power to prosecute for the same offense), superseded by statute on other grounds, Indian Civil Rights Act, 25 U.S.C. §§ 1301-1303; see also United States v. Lara, 541 U.S. 193, 208-09 (2004); United States v. Elk, 561 F.2d 133, 134-35 (8th Cir. 1977).

22. See United States v. McBratney, 104 U.S. 621, 624 (1881). See generally Clinton, supra note 17 . 
on the basis of the Equal Footing Doctrine of the United States Constitution. ${ }^{23}$ This doctrine has been applied uniformly to all states to acknowledge state criminal jurisdiction, even where state constitutions or enabling acts contain waivers which disavow that the state comes into the union with any jurisdiction over Indian country therein. ${ }^{24}$

Outside of the context of a non-Indian on non-Indian crime, before the 1940s there was no specific authorization under law for Kansas state or county officials to play a role in criminal jurisdiction stemming from Indian country crimes.

\section{HISTORY OF THE KANSAS ACT ${ }^{25}$}

The Kansas Act was passed in 1940 to address reported gaps in jurisdiction over crimes between Indians occurring in Indian country within Kansas. $^{26}$ Legislative history of the Act relates a concurrence of factors, which were perceived to require the State of Kansas to have general jurisdiction over criminal matters occurring in Indian country within the state borders. ${ }^{27}$

\section{A. Stated Purpose of the Kansas Act}

Materials in the legislative history of the Kansas Act reported that federal statutes applicable to reservations in Kansas "do not provide a complete code for the maintenance of law and order within those reservations." ${ }^{28}$ Moreover, none of the four Indian tribes in Kansas were

23. McBratney, 104 U.S. at 624.

24. Draper v. Unites States, 164 U.S. 240, 247 (1896)

25. Act of June 8, 1940, ch. 276, 54 Stat. 249 (codified as amended at 18 U.S.C. § 3243 (2006)). The Act was titled a bill "To confer jurisdiction on the State of Kansas over offenses committed by or against Indians on Indian reservations.” Id.

26. See generally H.R. REP. NO. 1999 (1940) (noting that tribal courts no longer exist on Kansas reservations and the jurisdiction of federal courts only extends to limited categories of offenses).

27. See generally id. (stating that factors include the inadequacy of the federal criminal code to provide a complete code within reservations, lack of tribal courts, administrative difficulty due to the breaking up of reservations, and the desire of the Indians that the State courts exercise jurisdiction). Congress maintains plenary authority to change the law designating criminal jurisdiction on Indian lands. See Washington v. Confederated Bands \& Tribes of Yakima Nation, 439 U.S. 463, 470-71 (1979).

28. H.R. REP. NO. 1999, at 3 (asserting that "[i]nsofar as offenses committed by Indians against Indians are concerned, virtually the only acts penalized by Federal law are the ten major crimes listed in section 328 of the Criminal Code”). 
then operating tribal courts to enforce a general criminal code. ${ }^{29}$ Consequently, there was a concern that if the State did not step into the gap to prosecute criminal offenses on Indian land, criminal conduct would go unchecked. The report from the Committee on Indian Affairs submitted to Congress claimed that many criminal acts "universally decreed wrongful ... may escape punishment if the present situation is not remedied." 30

Since federal criminal jurisdiction was limited by statute and tribal nations were not then asserting their own jurisdiction, even without specific authority, enforcement of general criminal law often fell to Kansas state authorities. For some time, Kansas authorities had simply been accepting jurisdiction over criminal cases brought before them. ${ }^{31}$ Under what appeared to be a practice of convenience, rather than one specified in law, the state of Kansas, rather than federal authorities, prosecuted offenses occurring between Indians in Indian country. ${ }^{32}$ This was done even when the conduct involved offenses under the Major Crimes Act. $^{33}$ Continuation of this practice appeared to be facing scrutiny, however. The legislative report referenced a challenge to state prosecution of criminal acts on reservations in Kansas. ${ }^{34}$ The memorandum included in the report opined that the state actually had no authority to exercise such jurisdiction. ${ }^{35}$ One argument in support of the Kansas Act claimed that passage of the Act would "merely confirm a relationship which the State has willingly assumed, which the Indians have willingly accepted, and which has produced successful results, over a considerable period of years." 36

Another reason reported to Congress in support of the Kansas Act related to the complexity of criminal jurisdiction in "Indian country.,"37 The intricacy of this jurisdictional framework resulted largely from the disposition of allotment and trust lands in Kansas. Out of approximately

29. Id. at 4; see also John Rainwater, Criminal Jurisdiction over Tribal Land in Kansas: Dueling Sovereigns, J. KAN. B. Ass'N., Feb. 1999, at 25 n.48.

30. H.R. REP. NO. 1999, at 4.

31. Id. This practice occurred "with the approval of the tribes concerned" and this "exercise of criminal jurisdiction by the State courts was to their general satisfaction." Id.

32. See id.; Rainwater, supra note 29, at 25.

33. H.R. REP. No. 1999, at 4; Rainwater, supra note 29, at 25.

34. H.R. REP. No. 1999, at 4.

35. Id.

36. Id. at 5 .

37. Negonsott v. Samuels, 507 U.S. 99, 102-03 (1993) (describing criminal jurisdiction in "Indian country"). See generally 18 U.S.C. § 1151 (2006) (providing current definition for "Indian country”). 
115,000 acres of reservation land allotted, only 34,937 acres remained in trust, interspersed among the other holdings. ${ }^{38}$ The remaining unrestricted 80,063 acres were reported to be under state, rather than federal jurisdiction. ${ }^{39}$ When an offense was committed on a reservation, assertion of federal criminal jurisdiction over the act could occur only after determining that the offense occurred on trust land rather than unrestricted land. ${ }^{40}$ The report reasoned that due to the "checkerboard" nature of the trust lands, criminal acts between Indians on land within a reservation that did not constitute trust land were already properly under Kansas state jurisdiction. ${ }^{41}$ The report went on to assert that the burden of making this determination was onerous and could be eliminated by passing general criminal jurisdiction to the state. ${ }^{42}$

38. H.R. REP. No. 1999, at 4. The Indian General Allotment Act, commonly referred to as the Dawes Act, ch. 119, 24 Stat. 388 (1887), repealed by Act of June 18, 1934, ch. 576, 48 Stat. 984, had a similar effect on Indian lands across America. See G. William Rice, The Indian Reorganization Act, The Declaration of Rights of Indigenous Peoples, and a Proposed Carcieri "Fix": Updating the Trust Land Acquisition Process, 45 IDAHO L. REV. 575, 576-77 (2009). The Dawes Act forced application of American property and inheritance laws to Indian lands. Id. This divided tribal lands among individual tribal citizens. Id. These lands were often manipulated into being sold. Id. This had the effect of dramatically diminishing Indian lands. Id. Between 1887 and 1934, Indian landholdings shrank from 138,000,000 acres to 48,000,000 acres. Id.; see also Michael Duma, Note, Kansas Criminal Jurisdiction in Indian Country: Why the Kansas Act [18 U.S.C. $\S$ 3243] Is Unnecessary, Outdated and Unfair, 50 WASHBURN L.J. 685 (forthcoming 2011) (describing that the purpose of the Dawes Act was to move Indians away from a communal lifestyle by introducing private interests in land and selling tribal land to non-Indian settlers, thereby facilitating assimilation).

39. H.R. REP. No. 1999, at 4.

40. "Under existing law if an offense is committed within the reservation boundaries, an inquiry must first be made to determine whether the place of commission is trust land or unrestricted land, in order to ascertain whether the State or the Federal authorities have jurisdiction.” Id.

41. Id.

As Federal jurisdiction in criminal matters is at present almost wholly confined to tribal and restricted lands, and as the general criminal jurisdiction of the several States extends to unrestricted Indian allotments, it follows that considerably more than two-thirds of the area of these four reservations is already subject to the criminal laws, police and courts of Kansas.

Id. "[S]ince the checkerboard pattern of the land technically subject to Federal jurisdiction makes other arrangements difficult of administration, the conferring of jurisdiction in criminal matters on the State of Kansas, as proposed in H.R. 3048, appears desirable.” Letter from E.K. Burlew, Acting Sec'y of the Interior to Hon. Will Rogers, Chairman Comm. on Indian Affairs, House of Representatives, H.R. REP. NO. 1999, at 2.

42. H.R. REP. No. 1999, at 4-5. 


\section{B. History Behind the Kansas Act}

1. Archived Records Show the Initial Purpose of the Bill Was to Transfer Criminal Jurisdiction from Federal Authority to the State of Kansas

Efforts to pass the Kansas Act did not begin the year it was enacted. Rather, a legislative initiative designed to transfer to the state the power to prosecute offenses occurring on reservations began at least two legislative sessions earlier. In March of 1938, Potawatomi Agency ${ }^{43}$ Superintendent Bruce contacted federal legislators from Kansas, proposing a bill to give the state of Kansas exclusive jurisdiction over criminal cases occurring on Indian lands in Kansas. ${ }^{44}$ This proposal was apparently prompted by indications that federal prosecutors planned to increasingly assert authority over offenses on reservations. A letter written by the U.S. Attorney for Kansas, Summerfield Alexander, expressed his intent to have federal authorities prosecute all crimes on the "Pottawatomie" [sic] reservations. ${ }^{45}$ The reason for the U.S. Attorney's interest apparently emerged from a case in which the Jackson County Sheriff sought federal assistance in apprehending a man named

43. Potawatomi Agency is the precursor to the Horton Indian Agency, under the Bureau of Indian Affairs. Potawatomi, Kickapoo, Sac (Sauk) and Fox, and Iowa Tribes were under this agency. Guide to Archival Holdings, at NARA's Central Plains Region (Kansas City), Record Group 75, Records of the Bureau of Indian Affairs, http://www.archives.gov/central-plains/kansascity/holdings/rg-050-099.html\#75 (last visited June 1, 2011); Potawatomi Indian Agency (Kansas), FAMILY SEARCH, https://wiki.familysearch.org/en/Potawatomi_Indian_Agency_(Kansas) (last visited June 1, 2011).

44. Letter from H.E. Bruce, Superintendent, Potawatomi Agency, to Hon. Wm. P. Lambertson, Member of Cong. (March 9, 1938) (on file with the National Archives at Kansas City). The opening paragraph read, "Dear Mr. Lambertson: Attached is a confidential copy of my report to the Indian Office on the bill you agreed recently to introduce for us so as to give the courts of the state of Kansas exclusive jurisdiction over offenses committed within reservation areas.” Id.

45. Letter from Summerfield S. Alexander, U.S. Attorney for Kan., to Warden L. Noe, Cnty. Attorney for Jackson Cnty. (November 12, 1937) (on file with the National Archives at Kansas City). The letter states: "Dear Mr. Noe: The department has under consideration the question of prosecuting in the Federal courts all crimes committed by or against the person and property of Indians in the Pottawatomie [sic] Reservation." Id. The letter went on to seek information about cases in Jackson County in which Indians were prosecuted for offenses on "the Indian Reservation" and information "as to any Indian that may be in any jail in your county" and "as to any Indian that may be serving time in any State penal institution.” Id. Another letter, dated November 13, 1937, but mailed January 18, 1938, followed, outlining seven points under which under which federal authorities "should take over and prosecute crimes committed by Indians or . . . against the person or property of Indians... within the limitations indicated by Federal statutes." Letter from Summerfield S. Alexander, U.S. Attorney for Kan., to Warden L. Noe, Cnty. Attorney for Jackson Cnty. (November 13, 1937, mailed January 18, 1938) (on file with the National Archives at Kansas City). 
Louis Wezo. ${ }^{46}$ This request must have caught the attention of officials in Washington. The U.S. Attorney General's Office criticized Mr. Alexander for decisions that were being made in criminal cases involving Indians on reservations in Kansas. ${ }^{47}$ The U.S. Attorney General believed these cases should be prosecuted in federal court. ${ }^{48}$

Communication from Superintendent Bruce to U.S. Attorney Alexander following up on this development urged transfer of jurisdiction over these cases from federal to state authorities: "From a practical, administrative standpoint, however, there are many excellent reasons why (so far as the reservations in Kansas are concerned) the United States Attorney and the Federal Court should permit the state courts to continue to assume jurisdiction over all criminal matters involving Indians.....49 Superintendent Bruce outlined six points in support of the proposed transfer. These points included: (1) the lack of tribal courts on the four Kansas reservations to deal with minor offenses; ${ }^{50}$ (2) the fact that Jackson and Brown counties did not charge the Indian Service for the care of indigent Native people who were institutionalized as a result of proceedings heard in courts sitting in those counties; ${ }^{51}$ (3) the difficulty in determining what cases would fall under federal jurisdiction in light of the dramatic reduction of land allotted to

46. Letter from H.E. Bruce, Superintendent, Potawatomi Agency, to W. L. Noe, Cnty. Attorney for Jackson Cnty. (November 19, 1937) (on file with the National Archives at Kansas City).

47. Id.

Dear Mr. Noe:

In order that you may have a background for understanding the United States Attorney's letter of November 12 to you regarding the question of prosecuting in Federal Court all crimes committed by or against the person or property of Indians of the Potawatomi Reservation, I should like to state that this question grew out of the efforts of the sheriff of Jackson County to obtain the assistance of agents of the Federal Bureau of Investigation in apprehending Louis Wezo.

Mr. Alexander was called upon, apparently, for a report by the Attorney General's Office as a result of which it seems that the Attorney General has cited Mr. Alexander to certain decisions affecting the jurisdiction of Federal Court in cases of this kind and intimated that the prosecutions of this nature properly belonged in Federal Court rather than State Court.

Id.

48. Id.

49. Letter from H. E. Bruce, Superintendent, Potawatomi Agency, to Mr. S.S. Alexander, U.S. Attorney for Kan. (March 5, 1938) (on file with the National Archives at Kansas City).

50. Id. The letter states: "I find no record that a tribal Indian court to deal with misdemeanors and minor civil matters has been available to the Indians of the four Kansas reservations at any time within the last 35 or 40 years." Id.

51. Id. (referring to Jackson and Brown County courts exercising jurisdiction over juvenile delinquency and insanity cases). 
people in the four Kansas tribes remaining in trust; ${ }^{52}$ (4) a concern that a question of appropriate jurisdiction could undercut the cooperative relationship between county authorities and the "Indian Service" and could also be raised as a defense in "borderline cases" in a way that obstructs justice ${ }^{53}(5)$ the four Indian tribes in Kansas passed resolutions supporting a bill to transfer jurisdiction of enumerated federal felonies from federal to state courts; ${ }^{.4}$ and (6) administering a system of prosecuting Indian criminal cases in federal court would require expense, effort, and inconvenience that would not be necessary if the same cases were heard in the nearby state courts. ${ }^{55}$

Near the same time, the four Indian tribes in Kansas passed resolutions seeking transfer of criminal jurisdiction on reservations from federal court to state court. ${ }^{56}$ The Kickapoo tribal council passed a resolution on February 24, 1938, requesting that Congressman William Lambertson introduce a bill in Congress effectuating that transfer. ${ }^{57}$ On

52. Id. The letter highlights that of 115,900 allotted acres, only 34,937 remained in trust and of 1313 Native people to whom allotments were initially made, only 132 retained trust title. Id. The letter concludes that "it is inadvisable to set up jurisdiction requirements whereby a criminal matter involving one Indian must be taken into one court and the identical offense involving another Indian into a different court." Id.

53. Id. The letter states:

If the question of what court shall have jurisdiction becomes a factor in Indian cases, it not only will serve to weaken the very effective cooperation which has developed between county authorities and the Indian Service, but it will encourage the shyster lawyer (there always will be some of these around an Indian reservation) to raise the question of jurisdiction in all borderline cases in an effort to obstruct justice while Id. increasing his fee proportionately.

54. Id.

In the Indian Office at Washington, the suggestion was made that a bill might be introduced in Congress transferring jurisdiction from Federal to state courts of the felonies now enumerated by federal law as applying on Indian reservations, and from the council resolutions hereto attached, you will note that all four Indian tribes under this jurisdiction definitely and positively favor such an arrangement and wish to conform to Id. state law and be under the jurisdiction of the state courts.

55. Id. Prosecuting Indian cases in Federal court would require multiple and long trips to Topeka, Kansas City, and Wichita for grand jury action, obtaining warrants, conducting arraignments and preliminary hearings, and hearing trials. Id. The same matters could be resolved in less time and with less expense in the nearby state courts, eight miles from the reservation. Id.

56. It should be noted that the tribes never consented to give up their own jurisdiction, nor did the tribes consent to a scenario where multiple prosecutions for the same offenses could occur.

57. Resolution of the Kickapoo Council, Robert Masquat, Sec'y, Kickapoo Council (February 24, 1938) (on file with the National Archives in Kansas City). This resolution addressed two unrelated issues. The second paragraph addressed proposal of legislation passed by a five to one vote and read:

BE IT FURTHER RESOLVED by the Kickapoo tribal council that the Commissioner of 
March 1, 1938, the Sac and Fox Tribe passed a similar resolution, which specifically contemplated the transfer of jurisdiction to include "major crimes or felonies ... defined by Federal law."58 The same day, the Iowa tribe approved, by a vote of four to one, a resolution to transfer jurisdiction of all criminal matters to state and local courts. ${ }^{59}$ Minutes of the Potawatomi Business Committee reflect that on March 4, 1938, the Potawatomi Tribe also endorsed a resolution to transfer jurisdiction "of the eight major crimes defined by Federal law” to state courts. ${ }^{60}$ The fact

Indian Affairs and Honorable Wm. P. Lambertson, Congressman from this district of Kansas, be requested to take steps to have a bill introduced in Congress transferring from Federal to state courts exclusive jurisdiction to prosecute and punish Indians and others Id. for crimes now defined by Federal law as applying to ward Indians and trust Indian land.

58. Resolution of the Sac \& Fox Tribe, C.W. Rabidoux, Chairman, John Connell, Sec’y, Sac \& Fox Tribe (March 1, 1938) (on file with the National Archives in Kansas City).

BE IT RESOLVED, that the Sac \& Fox Indians under the jurisdiction of Potawatomi Indian Agency desire to continue to recognize the authority of county, state and local officials over trust land and ward Indians in all matters involving law and order and request the Commissioner of Indian Affairs to ask Congress to enact special legislation transferring from Federal Courts to state courts exclusive jurisdiction in the major crimes or felonies now defined by Federal law as applying to lands held in trust for Indians or cases involving ward Indians.

Unanimously passed at a meeting held at Reserve, Kan., on March 1, 1938, with all council members present.

Id.

59. Resolution of the Iowa Tribe of Indians, John DeRoin, Chairman, Leonard Fee, Sec'y, Iowa Tribe of Indians (March 1, 1938) (on file with the National Archives in Kansas City).

BE IT RESOLVED, that the Iowa tribe of Indians of Kansas and Nebraska under the jurisdiction of Potawatomi Indian Agency, Mayetta, Kansas, long have submitted without question to the jurisdiction of local, county and state courts in all criminal matters, marriage and divorce laws, juvenile delinquency matters, etc., and desire to continue to look to county and state authorities for police protection and law enforcement among them on an equality with the other races and peoples in the community.

BE IT RESOLVED, that to accomplish the foregoing purpose the Commissioner of Indian Affairs is hereby requested to endorse a bill in Congress to authorize a transfer of jurisdiction from Federal Court to state and local courts of all criminal matters which now, under Federal law, being exclusively under the Federal Court because the crime involves the person of a ward Indian or is committed upon land held in trust by the United States for Indians of one of the four tribes in Kansas under Potawatomi Indian Agency.

BE IT FURTHER RESOLVED THAT Congressman William P. Lambertson be informed of our report by copy of this resolution.

Adopted by a vote of 4 for and 1 against at a called meeting on March 1, 1938, at the home of John DeRoin, at which a quorum was present.

Id.

60. Minutes of Meeting, Potawatomi Bus. Comm., Ernest Seymour, Chairman, Frank Moore, Sec'y, Potawatomi Tribe (March 4, 1938) (on file with the National Archives at Kansas City). The minutes covered several issues addressed by the business committee during the March 4 meeting. The fifth paragraph reads:

By a vote of 5 to 2 the committee adopted a resolution asking the Commissioner of Indian Affairs to recommend a bill to Congress amending present criminal laws so as to 
that all four tribes passed these resolutions within days of each other suggests a coordinated initiative. What is not clear is whether the initiative was prompted by Superintendent Bruce or whether his actions regarding the legislation were responsive to concerns of the tribes after hearing of the U.S. Attorney's interest in more regularly asserting federal jurisdiction.

A few days after adoption of the tribal resolutions, Congressman Lambertson introduced House Resolution 9757, “A BILL To relinquish jurisdiction to the State of Kansas to prosecute Indians or others for offenses committed on Indian reservations."61 This bill was the precursor to what became the Kansas Act two years later. However, it differed from the Kansas Act in a significant way. The 1938 version of this bill read:

Be it enacted by the Senate and House of Representatives of the United States of America in Congress assembled, That hereafter section 548 of title 18 and sections 217 and 218 of title 25 of the United States Code shall not apply to Indian reservations or other Indian country in the State of Kansas; and jurisdiction is hereby relinquished to the said State of Kansas to prosecute and punish Indians or others for the commission of offenses within Indian reservations or other Indian country within the State to the same extent as for offenses committed elsewhere within the State. ${ }^{62}$

The language preventing application of "section 548 of title 18" and sections " 217 and 218 of title 25" in Kansas, if enacted, would have prevented federal prosecution and punishment of the major crimes enumerated under federal law in Indian country in the state. ${ }^{63}$ It would also have prevented the federal government from asserting authority under the General Crimes Act. ${ }^{64}$ This would have resulted in state authorities in Kansas having exclusive jurisdiction over criminal offenses occurring on reservations. Shortly after, Senator Capper introduced an

transfer jurisdiction from Federal to State courts of the eight major crimes defined by Federal law as applying to the persons of Ward Indians or property held in trust for Indians by the United States, so far as the Indians in Kansas are concerned. Id.

61. H.R. 9757, 75th Cong. (3d Sess. 1938).

62. Id.

63. These were respectively the code sections for the Major Crimes Act and the General Crimes Acts of the time. See 18 U.S.C. §§ 1153, 1152 historical and revision notes (2006).

64. General Crimes Act, 18 U.S.C. § 1152 (providing for prosecution of crimes between nonIndians and Indians occurring in Indian country). 
identical bill in the United States Senate. ${ }^{65}$ Both bills were referred to the Committee on Indian Affairs. ${ }^{66}$

Correspondence during and shortly after this time reinforce that a transfer of jurisdiction to state authorities, rather than concurrent jurisdiction, was the objective of the 1938 bill. John DeRoin, Chairman of the Iowa Tribal Executive Committee wrote to Senator Capper, making this point while asking that the senator introduce a version of the House bill in the Senate: "As matters now stand, there are certain cases handled in State Court and the Indians generally would prefer to be under the exclusive criminal jurisdiction of the State Courts and on an equality with white people in this regard.” ${ }^{67}$ A letter from Superintendent Bruce to the Commissioner of Indian Affairs reiterated that the intent was the transfer of jurisdiction but noted that the U.S. Attorney seemed opposed. In fact, it appeared that the U.S. Attorney for Kansas was preparing to follow up on his plan to assert jurisdiction over all cases that could legally be brought in federal court. ${ }^{68}$ In the letter, Bruce noted that state authorities had been handling criminal cases occurring on reservations and that the bill would "merely confirm the jurisdiction which the state has willingly assumed over a long period of years, without any questions arising until now., ${ }^{69} \mathrm{He}$ also reiterated that all four tribes in Kansas supported this bill. ${ }^{70}$

65. S. 4026, 75th Cong. (1938).

66. H.R. 9757; S. 4026.

67. Letter from John DeRoin, Chairman, Iowa Tribal Exec. Comm., to Arthur Capper, U.S. Senator (May 5, 1938) (on file with the National Archives at Kansas City).

68. Letter from H.E. Bruce, Superintendent, Potawatomi Agency, to Comm'r of Indian Affairs (Mar. 9, 1938) (on file with the National Archives at Kansas City).

I talked with the U.S. Attorney this week but he does not seem inclined to take the matter up further with the Department of Justice headquarters in Washington. In substance, his position seems to be that he will assume jurisdiction over any case that apparently properly belongs in Federal Court until such time as existing law is changed. Perhaps the Office may wish to recommend to the Attorney General that the Department of Justice ask the U.S. Attorney to permit all cases to be handled in state courts as heretofore, in accordance with the apparent wish of the Indians, until such time as Congress has acted upon the bill which Congressman Lambertson probably has introduced by now has been enacted into law.

Id.

69. Id.

70. See id. 


\section{The Next Draft of the Bill Proposed Concurrent Jurisdiction Rather than Transferred Jurisdiction}

In the face of opposition from the Department of Justice, this first version of the legislation was ultimately defeated. ${ }^{71}$ By the end of the calendar year, however, plans were made to introduce a slightly altered version of the bill in the next legislative session. Rather than seek a total transfer of jurisdiction, the next legislative effort sought to have concurrent-not exclusive-jurisdiction over crimes occurring in Indian country in Kansas extend to state authorities. ${ }^{72}$ Superintendent Bruce believed this approach would secure Department of Justice approval. ${ }^{73}$

Groundwork to demonstrate support for the initiative once again involved tribal nations in Kansas enacting resolutions in favor of the bill. However, resolutions appeared to come about through a slightly different mechanism this time around. Rather than the tribes adopting resolutions worded in a way organically developed by each tribe, identical resolutions were authorized by three tribes. Materials in the National Archives provide some explanation in that they include a fill-in-theblank copy of a resolution. ${ }^{74}$ On December 5, 6, and 7, 1938, the

71. See Letter from H.E. Bruce, Superintendent, Potawatomi Agency, to Wm. P. Lambertson, Member of Cong. (December 13, 1938) (on file with the National Archives at Kansas City) ("A friend in the Indian Office has drafted a new proposed Bill to provide for the surrender of concurrent jurisdiction and I am inclosing copies of resolutions passed by the Councils of the Kickapoo, Iowa and Sac \& Fox Tribes, endorsing this bill.”); see also Letter from E.K. Burlew, Acting Sec'y of the Interior, to Director of the Bureau of the Budget, (June 2, 1938) (on file with the National Archives at Kansas City) (referring to the Acting Attorney General's concerns about relinquishing jurisdiction under the pending H.R. 9757)

72. See Letter from E.K. Burlew, supra note 71.

73. Letter from H.E. Bruce, supra note 71. Senator Bruce wrote "[t]his Bill did not pass, however, and the recommendation of the Department of Justice on the Bill was against surrender of complete jurisdiction, although I believe the Department of Justice will not oppose the surrender of concurrent jurisdiction.” Id.

74. The model resolution read:

Resolution Of the Tribal Council of the Tribe of Indians in the State of Kansas.

Be it Resolved, That the Tribal Council of the Tribe of Indians under the jurisdiction of the Potawatomi Agency, Horton, Kansas, desires that the local county and state authorities of the State of Kansas shall exercise jurisdiction in all matters involving law and order on their reservation and request that the Commissioner of Indian Affairs and the Senators and Representatives of the State of Kansas endeavor to procure legislation by Congress to carry this into effect and to confer concurrent jurisdiction on the State of Kansas to take appropriate action in the case of all felonies and misdemeanors committed by or against Indians, as well as all other such cases, and committed on their reservations, including all trust lands as well as fee patent lands within said reservation.

Passed at a meeting held at , Kansas, on , 1938, with council members present. 
Kickapoo Tribe, Iowa Tribe, and Sac and Fox Tribe, respectively, passed resolutions that essentially filled in the blanks of this model resolution. ${ }^{75}$ Significantly, these resolutions sought legislation providing concurrent jurisdiction to Kansas rather than a transfer of criminal jurisdiction. ${ }^{76}$ It is also significant that there is no corresponding resolution in the archived materials from Potawatomi Nation. ${ }^{77}$ The materials in the National Archives pertaining to this second bill document support from only three out of the four tribes in Kansas. At that point in the historical record, there was no evidence of opposition on the part of Potawatomi Nation, only a failure to act on the matter one way or the other. ${ }^{78}$

Undated model resolution (on file with the National Archives at Kansas City). Signature lines for the Secretary and Chairman followed the text. Id. The word "concurrent" is a handwritten edit to one copy of the model resolution in the archived materials. See id. Interestingly, the archived materials also contain an undated handwritten note of unknown authorship. The note reads:

After one tribe adopts this or a similar resolution, the others might "endorse the resolution adopted by the __ tribe on ___ 1938, to the effect that," etc.," [sic] so the resolutions will not all read exactly the same with no explanation of how they happened to be just the same.

The resolution could be preceded by a number of Whereas-es [sic] setting forth the reasons for the resolution.

Undated handwritten note (on file with the National Archives at Kansas City). Apparently, the approach proposed in this note was not adopted. Instead, three resolutions based upon the model, without explicit explanation of how or why they read exactly the same, were adopted. See also Letter from H.E. Bruce, supra note 71 ("A friend in the Indian Office has drafted a new proposed Bill to provide for the surrender of concurrent jurisdiction and I am inclosing copies of resolutions passed by the Councils of the Kickapoo, Iowa, and Sac \& Fox Tribes, endorsing this bill. You will note that this action of all three Tribes was unanimous.").

75. Resolution of the Executive Council of the Iowa Tribe of Indians in the State of Kansas, John DeRoin, Chairman, Leonard Fee, Sec'y (Dec. 6, 1938) [hereinafter Iowa Resolution] (on file with National Archives at Kansas City); Resolution of the Tribal Council of the Kickapoo Tribe of Indians in the State of Kansas, Robert Masquat, Sec'y (Dec. 5, 1938) [hereinafter Kickapoo Resolution] (on file with the National Archives in Kansas City); Resolution of the Tribal Council of the Sac \& Fox of Missouri Tribe of Indians in the State of Kansas, C.W. Robidoux, Chairman, John Connell, Sec'y (Dec. 7, 1938) [hereinafter Sac \& Fox Resolution] (on file with the National Archives in Kansas City).

76. Iowa Resolution, supra note 75; Kickapoo Resolution, supra note 75; Sac \& Fox Resolution, supra note 75.

77. The December 13, 1938 letter from Superintendent Bruce to Congressman Lambertson provides an explanation why there was no resolution from Potawatomi at that time.

The Potawatomi Tribe a year ago through its business Committee recommended the surrender of complete jurisdiction, but the present Business Committee of the Tribe is reluctant to take action without first discussing the matter in a general tribal meeting. I believe ultimately the Potawatomies also will give their indorsement to this move.

Letter from H.E. Bruce, supra note 71. But see discussion infra Part III.B.2.

78. Other letters, which did not appear in the legislative history, record that the Potawatomi Business Committee opposed passage of the Act. See infra Part III.B.3. 
On January 5, 1939, in accordance with the wishes of three tribes in Kansas, House Resolution 3048 and Senate Bill 372 were introduced in both the House and Senate. ${ }^{79}$ Key language in both stated:

jurisdiction is hereby conferred on the State of Kansas over offences committed by or against Indians on Indian reservations, including trust or restricted allotments, within the state of Kansas, to the same extent as its courts have jurisdiction over offenses committed elsewhere within the State in accordance with the laws of the State., ${ }^{80}$

3. Contrary to the Legislative History, Archived Records Show Not All Indian Tribes in Kansas Supported the Bill

Communications during the following months indicate that the absence of a resolution from Potawatomi Nation was not merely the result of a lack of opportunity to fully address the matter. Rather, signs of opposition to the bill during this time exist in archived records. A hint of the opposition appeared in a May 11, 1939 letter from Superintendent Bruce to Congressman Lambertson, which reported, "Some of the agitators on Potawatomi have gotten an entirely wrong conception of what this legislation proposes which I will correct at a council meeting in about a week...., ${ }^{81}$ This passage is perhaps responsive to communications from Potawatomi Chairman James Wahbnosah to Representative Will Rogers, Chairman of the House Committee on Indian Affairs. If so, it was soft-pedaling the Potawatomi tribe's position. A May 8, 1939 telegram from Chairman Wahbnosah to Representative Rogers read: "POTAWATOMI INDIAN COUNCIL REQUESTS THAT HOUSE BILL 3048 BE NOT PASSED LETTER FOLLOWS."82 A portion of the letter that followed stated: "The Resolution was presented by the Superintendent of this reservation and was turned down by a majority of the Business Committee. Its presentation was a forgery. We did not want it." ${ }^{\text {"3 }}$ Another letter from

79. S. 372, 76th Cong. (1939); H.R. 3048, 76th Cong. (1939).

80. S. 372; H.R. 3048.

81. Letter from H.E. Bruce, Superintendent, Potawatomi Agency to W.P. Lambertson, Member of Cong. (May 11, 1939) (on file with the National Archives at Kansas City).

82. Telegram from James Wahbnosah, Potawatomi Bus. Comm. Chairman, to Rep. Will Rogers House Indian Comm. (May 8, 1939) (on file with the National Archives at Washington DC); see also Motion for Leave to File Brief out of Time \& Brief of Amicus Curie of the Iowa Tribe of Kan. and Neb. et al. in Support of Petitioner at 17-19, Negonsott v. Samuels, 507 U.S. 99 (1993) (No. 915397).

83. Telegram from James Wahbnosah, supra note 82; see also Motion for Leave, supra note 82, 
Chairman Wahbnosah to Representative Rogers almost a year later on April 25, 1940, noted that House Resolution 3048 had been approved by the House Indian Affairs committee but that the Potawatomi Tribe nevertheless opposed the bill. $^{84}$

Even though these objections from the Potawatomi Business Council preceded issuance of the report from the Committee on Indian Affairs, no mention of Potawatomi's objection is noted in the Committee's report on the bill or anywhere else in the legislative history. Indeed, a major reason recited in support of the legislative history is that all four tribes in Kansas were in favor of the legislation. ${ }^{85}$ Not only was there a lack of unanimity among the four tribes, but when looking at tribal populations, the three tribes that approved of the bill did not even constitute a majority of the Native people in Kansas. A letter from the Potawatomi Chairman to Representative Rogers stated: "The Business Committee of the Prairie Band Potawatomi tribe of Indians represents eleven-hundred of the sixteen-hundred Indians of Kansas . . . I beg to urge all you can in your power to stop this House Resolution 3048.” ${ }^{86}$ Thus, representatives of a majority of Indians in Kansas opposed the bill that became the Kansas Act.

at 17. It is not clear what was purportedly a forgery since no resolution claiming to originate from Potawatomi Tribe was presented in relation to this version of the bill.

84. Letter from James Wahbnosah, Potawatomi Bus. Comm. Chairman, to Hon. Will Rogers, House Indian Comm. (Apr. 25, 1940) (on file with the National Archives at Washington, D.C.). The letter states that the real purpose of the bill was to help counties evade a recent federal court decision requiring the counties to return taxes collected from illegal taxation of Indian lands. Id.

85. "Since the tribes concerned desire the authorization and continuance of the criminal jurisdiction hitherto exercised by the State courts ...the conferring of jurisdiction in criminal matters on the State of Kansas, as proposed in S. 372, appears desirable.” S. REP. No. 1523, at 2 (1939) (reported by Elmer Thomas, Chairman, Senate Comm. on Indian Affairs) (quoting Letter from E.K. Burlew, Acting Sec'y of the Interior, to Sen. Elmer Thomas, Chairman, Senate Comm. on Indian Affairs (Mar. 16, 1940) [hereinafter Letter to Sen. Elmer Thomas] (on file with the National Archives at Kansas City)). "The four tribes located on the Kansas reservations do not desire reestablishment of the tribal courts, but have expressed a wish that the jurisdiction hitherto exercised by the State courts be continued." Id. at 4. "The proposed relinquishment of jurisdiction to the State of Kansas appropriately extends to those offenses which are provided for in existing Federal statutes as well as to those which are not. The State courts have in the past exercised jurisdiction over offenses of both types to the general satisfaction of the tribes; the Indians desire that they continue to do so. .." Id. Identical quotes appear in the report from the House Committee on Indian Affairs. H.R. REP. No. 1999, at 2-3 (1940) (reported by Will Rogers, Chairman, House Comm. on Indian Affairs) (quoting Letter from E.K. Burlew, Acting Sec'y of the Interior, to Sen. Will Rogers, Chairman, House Comm. on Indian Affairs).

86. Letter from James Wahbnosah, Chairman, Potawatomi Bus. Comm., to Rep. Will Rogers, House Indian Comm. (May 16, 1939) (on file with the National Archives at Washington, D.C.). 


\section{The Kansas Act Evolves to Its Final Form}

After the House and Senate Committees on Indian Affairs studied House Resolution 3048 and Senate Bill 372, they issued nearly identical reports. The committee reports were influenced by a letter from Acting Secretary Burlew, cited in each, noting that the bills as worded did

not express with entire accuracy the legal situation as it now exists or as intended to be created. The bill proposes to 'relinquish concurrent jurisdiction' to the State of Kansas, intending thereby to give the State jurisdiction of all types of crimes, whether major or minor, defined by State law. However, the Federal Government has exercised jurisdiction only over major crimes. Therefore, strictly speaking, this is not a case of relinquishing to a State jurisdiction concurrent with that of the United States, but a case of conferring upon the State complete criminal jurisdiction, retaining, however, jurisdiction in the Federal courts to prosecute crimes by or against Indians defined by Federal law. ${ }^{87}$

Following this analysis, Burlew proposed that the legislation be retitled, a bill "[t]o confer jurisdiction on the State of Kansas over offenses committed by or against Indians on Indian reservations." ${ }^{88}$ Burlew also proposed amended language for the text of the bill. ${ }^{89}$ Burlew's proposed wording was ultimately adopted and became the language of the bill's final form. ${ }^{90}$

Changing the functional language from "concurrent jurisdiction is hereby relinquished to the State of Kansas to prosecute Indians and others for offenses by or against Indians or others, committed on Indian reservations in Kansas," to "jurisdiction is hereby conferred on the State of Kansas over offenses committed by or against Indians on Indians reservations" ${ }^{\text {91 }}$ altered the reach of the Act. The plain language of relinquishing concurrent jurisdiction would have bestowed on Kansas authority to prosecute only those offenses addressed by federal law. The

87. Letter to Sen. Elmer Thomas, supra note 85.

88. Id.

89. Id.

90. See H.R. REP. NO. 1999, at 1 ("That jurisdiction is hereby conferred on the State of Kansas over offenses committed by or against Indians on Indian reservations, including trust or restricted allotments, within the State of Kansas, to the same extent as its courts have jurisdiction over offenses committed elsewhere within the State in accordance with the laws of the State: Provided, however, That nothing herein contained shall deprive the courts of the United States of jurisdiction over offenses defined by the laws of the United States committed by or against Indians on Indian reservations.")

91. S. 372 REP. No. 1523 (1939). 
language ultimately enacted conferred general criminal authority to the state, without regard for whether the offense existed in federal law or state law.

\section{Was the Kansas Act a Testing Ground for Similar Legislation in Other States?}

Did the Kansas Act come about because circumstances it sought to remedy were unique to the Kansas, or was the legislation designed to test the feasibility of implementing similar legislation throughout Indian country? There is evidence to support both hypotheses. Clearly, legislative history and correspondence related to the Act reference "peculiar factors which exist in the case of Kansas tribes" justifying passage of the Act. ${ }^{92}$ However, a letter from Superintendent Bruce to Senator Capper dated May 29, 1940, states "that the Indian Office in Washington is planning to recommend similar legislation for Indian areas in other states when the plan has been tried out in Kansas."93 When it comes to federal legislation providing for state jurisdiction in Indian country, the Kansas Act has received little attention. The more farreaching legislation, which invites state power into an otherwise federaltribal arena and has received much more attention for its broader applicability, was passed in $1953,{ }^{94}$ thirteen years after the passage of the Kansas Act. This controversial legislation delegated federal jurisdiction of criminal cases initially to five states-California, Nebraska, Wisconsin, Oregon, Minnesota ${ }^{95}$-and then, in 1958, to Alaska. ${ }^{96}$ When Public Law 280 was passed, it formally marked the federal policy initiative to terminate its special relationship with Indian tribes. ${ }^{97}$

92. Id. at 2 (quoting Letter to Sen. Elmer Thomas, supra note 85); see also supra Part III.A.

93. Letter from H.E. Bruce, Superintendent, Potawatomi Agency, to Sen. Arthur Capper (May 29, 1940) (on file with the National Archives at Kansas City). This letter was written shortly after passage of the Kansas Act and begins by thanking Senator Capper for informing Superintendent Bruce that the bill passed both houses of Congress. Id. Bruce goes on to state, "Based upon 27 years of Indian field experience, it is my conviction that a similar law and order setup is definitely needed over a large section of the Indian country.” Id.

94. Act of Aug. 15, 1953, Pub. L. No. 280, 67 Stat. 588 (1953).

95. Gary C. Randall \& Keith Telstad, Community Property Rules or American Indian Tribal Law-Which Prevails?, 31 IDAHO L. REV. 1071, 1075 (1995).

96. Felix Cohen, Handbook of Federal Indian Law 176 (Rennard Strickland et al. eds., 1982 ed.)

97. Id. at 175 . 


\section{Policy Considerations Used to Support the Federal Initiative}

Two reasons have been most often cited as support for this policy. ${ }^{98}$ The first, and arguably the most frequently cited, was the then-existing jurisdictional gap experienced in some tribal communities due to the lack of tribal judicial systems. ${ }^{99}$ This jurisdictional gap led to the general perception that tribal communities, lacking their own formal judicial systems, were unable to maintain law and order on their own. ${ }^{100}$ This was the underpinning for the transfer of legal authority from the federal government to those "mandatory" Public Law 280 states. $^{101}$

Secondly, Public Law 280's somewhat less frequently stated goal was to gradually shift the financial burden of prosecuting crimes in Indian Country to the states ${ }^{102}$ and, in doing so, to support the federal government's policy of assimilating Indian tribes and Indian people. ${ }^{103}$ This policy encouraged federal actions that supported mechanisms by which Indian people would be subsumed into the larger white society. ${ }^{104}$ Although Public Law 280 was not codified until 1953, the momentum actually began in the early $1940 \mathrm{~s}^{105}$ in what Felix Cohen describes as a period that is marked by the rejection of the principals of Indian reorganization. ${ }^{106}$ According to Cohen, the critics of Indian reorganization attacked it on two basic fronts. ${ }^{107}$ The first of those to criticize the policy were those that had economic interest in Indian lands and resources and believed that Indian Reorganization would undermine their interest. ${ }^{108}$

The second entity to criticize Indian reorganization policies was the federal government itself and, in particular, members of Congress who were unsatisfied with the Bureau of Indian Affairs and their oversight of

98. Emma Garrison, Baffling Distinctions Between Criminal and Regulatory: How Public Law 280 Allows Vague Notions of State Policy to Trump Tribal Sovereignty, 8 J. GENDER RACE \& JUST. 449, 451 (2004).

99. Id.

100. COHEN, supra note 96, at ch. 2, § E.

101. Ada Pecos Melton \& Jerry Gardner, Public LaW 280: Issues and CONCERnS FOR VICTIMS OF CRIME IN INDIAN COUNTRY (2004), available at http://www.oumedicine.com/ workfiles/College\%20of\%20Medicine/AD-Pediatrics/CSCCAN/Public\%20Law\%20280-final.pdf.

102. See Garrison, supra note 98 , at 451.

103. COHEN, supra note 96 , at $152-53$.

104. Id. at 153 .

105. Id. at 152 .

106. Id. at 153.

107. See generally id. ch. 2, § E.1.

108. Id. at 154 . 
Indian affairs, as well as the costly expenditures still being incurred to run the department. ${ }^{109}$ The lack of political will, along with the lack of resources and personnel as a result of the war in Europe, supported the sense of urgency for termination and assimilation of Indian tribes and Indian people. ${ }^{110}$ In spite of this viewpoint, there was recognition that Indian tribes were not yet in a position "to be turned loose""111 and that there remained obligations as yet unfulfilled by the federal government. $^{112}$

\section{The Kansas Act Foreshadows Federal Action}

With this historic context in mind, it is telling that the stated purpose of the Kansas Act foreshadows that of Public Law 280. In support of the Kansas Act, the legislative history asserts that not only did Kansas tribes lack a comprehensive code required to maintain law and order but also that they lacked a tribal court in which to enforce them. ${ }^{113}$ Additionally, the legislative history acknowledges that although federal statutes were applicable to Kansas tribes, there were jurisdictional gaps that needed to be addressed as a result of the lack of functioning tribal court systems. ${ }^{114}$

However, unlike those tribes affected in mandatory Public Law 280 states, the four Kansas tribes initially supported the transfer of criminal jurisdiction to the state. ${ }^{115}$ This is in marked contrast to what occurred upon the passage of Public Law 280, where affected tribes had no choice as to when states could assume jurisdiction on their reservations. ${ }^{116}$ The lack of tribal consent created controversy from the beginning due not only to the one-sided nature of the process but also because Public Law 280 clearly rejected principals of tribal self-determination and sovereignty. ${ }^{117}$ States covered by Public Law 280 that were required to assume jurisdiction over tribal communities also had issues with the legislation because they had to assume jurisdiction but were not funded by the federal government to do so. ${ }^{118}$




While there are some similarities between Public Law 280 and the Kansas Act, there remain significant and important differences. For instance, Public Law 280 extends state criminal jurisdiction over Indian reservations within those named states and, in doing so, eliminates the criminal jurisdiction formally held by the federal government. ${ }^{119}$ Most importantly, however, is that it did not eliminate tribal jurisdiction. ${ }^{120}$

In contrast, the Kansas Act provides criminal jurisdiction to the state, ${ }^{121}$ but the federal government retains statutory authority to prosecute major crimes and interracial crimes. ${ }^{122}$ This is an important distinction because the federal government remains obligated to assert jurisdiction over serious "offenses committed by or against Indians on Indian reservations."123 Moreover, the fact that the federal government did not relinquish its entire authority to the state of Kansas means that the federal government still provides financial and other support to Kansas tribes to support tribal self-determination. ${ }^{124}$

When the federal government relinquished its authority to those specific Public Law 280 states, it also stopped providing financial support to tribes to support tribal self-governance. ${ }^{125}$ This was an intended outcome in the relinquishment of federal jurisdiction and one that has had lasting impact on tribes in Public Law 280 states; specifically, the lack of federal funding has only further delayed the development of tribal justice systems. ${ }^{126}$

\section{Policing on Reservations: Identifying Areas of Concern}

In 2005, the National Institute of Justice released a comprehensive report that defined research priorities to evaluate the effectiveness of policing and law enforcement in Public Law 280 states. ${ }^{127}$ Although

119. Id. While the impact of Public Law 280 criminal jurisdiction is relatively straightforward, the issue of state civil jurisdiction is more complicated because it does not include state regulatory authority. Nevertheless, the passage of the act did not terminate tribal jurisdiction over civil cases.

120. Id.

121. COHEN, supra note 96, at 374.

122. See Major Crimes Act, 18 U.S.C. § 1153 (2006); General Crimes Act, 18 U.S.C. § 1152 (2006).

123. § 1153.

124. Garrison, supra note 98 , at 474.

125. Id. at 471 .

126. MELTON \& GARDNER, supra note 101.

127. U.S. DEP'T OF JUSTICE, PUblic LAW 280 AND LAW ENFORCEMENT IN INDIAN COUNTRYRESEARCH PRIORITIES 2 (2005), available at http://www.ncjrs.gov/pdffiles1/nij/209839.pdf. The report studied seventeen reservations in ten states in order to (1) compare crime rates in Public Law 
ultimately deciding that more research was necessary, some concerns were highlighted. ${ }^{128}$ Concerns raised by tribes in Public Law 280 states focused on the lack of effective law enforcement on reservations, as well as the infringement of tribal sovereignty. ${ }^{129}$ The report ultimately determined that it was most important to continue to collect important policing data in affected states with the possibility of creating more effective federal policies, such as "affirming concurrent tribal jurisdiction, encouraging voluntary interjurisdictional arrangements ... or authorizing tribally initiated retrocession" of Public Law $280 .{ }^{130}$

Because criminal jurisdiction as a result of the Kansas Act falls somewhere in between the historic criminal jurisdiction framework in non-Public Law 280 states and the relinquishment of federal authority envisioned as a result of Public Law 280, the state of Kansas and Kansas tribes have both similar and unique concerns. In spite of those differences, it is important to make a similar determination as to the ongoing necessity of the Kansas Act. This is especially true in light of the fact that those circumstances that precipitated the Kansas Act to begin with are no longer relevant in the twenty-first century. Kansas tribes now have tribal court systems that have evolved to address issues of law and order occurring on their respective reservations. There is no reason to have continued state interference with the administration of that justice. As such, the principle reason articulated in the legislation is moot. Furthermore, rather than being in a policy period that supports the termination of tribes, we are now in a policy period that recognizes the need for tribal sovereignty and self-determination. ${ }^{131}$ It is hard to reconcile that with the effects of the Kansas Act on the four tribal nations in Kansas.

\section{E. Do the Reasons that Gave Rise to the Kansas Act Still Exist?}

In addition to the claim that all Indian tribes in Kansas supported the legislation, another key reason proffered for passage of the Kansas Act was that none of the Indian nations in Kansas operated tribal courts. Without tribal courts to adjudicate crimes falling outside the reach of the

\footnotetext{
280 states; (2) determine the quality of law enforcement in those states; (3) evaluate federal "criminal justice funding and services;” (4) "evaluate retrocession, concurrent jurisdiction and cooperative agreement as options to alleviate” policing problems; and (5) explore potential legislative responses. Id.

128. See id. at 7.

129. Id.

130. Id. at 13 .

131. Garrison, supra note 98, at 474.
} 
Major Crimes Act, there was fear of a significant gap in maintaining law and order. Now, however, all four tribal nations in Kansas operate tribal courts. These tribal courts, among other duties, administer and adjudicate the criminal codes of each tribe. ${ }^{132}$ As such, offenses falling outside the limitations of the federal Major Crimes Act can now be prosecuted at the tribal level. Moreover, the Tribal Law and Order Act of 2010 expanded the reach of tribal courts. ${ }^{133}$ Therefore, the concern that a criminal act "universally decreed wrongful... may escape punishment" 134 is no longer a concern requiring the intervention of Kansas state authorities. Simply put, assertion of state criminal jurisdiction is not necessary to fill a vacuum of lawlessness.

Because the key reasons for passing the Kansas Act no longer exist, it is appropriate to ask whether the time for the Kansas Act has passed. Does the existence of the Kansas Act undercut modern principles of tribal sovereignty?

\section{EFFECT OF KANSAS ACT ON CRIMINAL PROSECUTIONS IN INDIAN COUNTRY WITHIN THE STATE OF KANSAS}

\section{A. A Description of Tribal-State-Federal Jurisdiction in Kansas}

Immediately following the enactment of the Kansas Act, it is likely that very little changed within tribal-state-federal jurisdiction in Kansas. It is documented that, although lacking in legal authority to do so, at least some county officials were actively prosecuting individuals for Indian country crimes in Kansas state courts beyond the non-Indian on nonIndian crimes that would have been the limitation on state authority at the time. ${ }^{135}$ This was likely the case from the 1940s into the 1980s, when the four tribes in Kansas began revitalizing tribal governments and exercising inherent powers that had remained dormant for decades

\footnotetext{
132. See Duma, supra note 38.

133. Tribal Law and Order Act of 2010, 25 U.S.C.A. § 2802 (Supp. 2010). Section 234 amends the Indian Civil Rights Act, 25 U.S.C. 1302 (2006), to broaden the sentencing authority of tribal courts in some instances from one year imprisonment, $\$ 5000$ fine, or both to three year imprisonment, $\$ 15,000$ fine, or both. § 2802. The sentencing authority is limited to a total of nine years and is limited to situations where the defendant is a repeat offender or where the crime if charged at the federal level would result in one year or more imprisonment. Id. To impose enhanced sentences, the tribe must provide court appointed counsel in indigent cases. Id.; see also Protection of Indian Arts and Crafts, Pub. L. No. 111-211, § 201-213, 124 Stat. 2258 (2010) (highlighting the changes that were incorporated into the Tribal Law and Order Act of 2010).

134. H.R. REP. No. 1999, at 4 (1940).

135. Id.
} 
because of crippling federal policies against tribal self-governance and an overall lack of tribal governments. Today, all four tribes have a functioning tribal court system, often with resources that match comparable county court allocations. ${ }^{136}$ All four tribes employ, either independently or with Bureau of Indian Affairs funding, tribal police departments. ${ }^{137}$ The tribal court systems exercise an array of jurisdiction from traffic matters to criminal and civil dockets akin to state counterparts, including child support enforcement, contract disputes, employee appeals, and the full range of criminal jurisdiction. ${ }^{138}$ As a matter of federal law, tribes are not recognized as having the authority to prosecute non-Indians following the Oliphant v. Suquamish Indian Tribe decision of the United States Supreme Court in 1978. ${ }^{139}$ As such, tribal criminal prosecutions are limited to American Indian individuals, either members or citizens of the prosecuting tribe, or members or citizens of another federally recognized tribe. ${ }^{140}$ Tribal sentencing power has also been limited by federal legislation and currently stands for most offenses at a maximum one-year sentence and $\$ 5000$ fine or, in limited circumstances, a three-year sentence and \$15,000 fine. ${ }^{141}$ Although the bulk of tribal criminal cases prosecuted within the Kansas tribes involve minor offenses that would be classified as misdemeanors under corresponding state law, serious violent offenses do occur and the tribes have recently exercised jurisdiction over such matters that would warrant major crimes status under the federal model or felony status under the state model. ${ }^{142}$

\footnotetext{
136. Miller, supra note 12 , at 27

137. See id.

138. Id. at 27-32.

139. 435 U.S. 191 (1978); N. Bruce Duthu, Implicit Divestiture of Tribal Powers: Locating Legitimate Sources of Authority in Indian Country, 19 AM. INDIAN L. REV. 353, 366-67 (1994).

140. See Duthu, supra note 139, at 366.

141. Tribal Law and Order Act of 2010, 25 U.S.C.A. § 2802 (Supp. 2010); Matthew Handler, Note, Tribal Law and Disorder: A Look at a System of Broken Justice in Indian Country and the Steps Needed to Fix It, 75 BrooK. L. ReV. 261, 297-98 (2009).

142. See, e.g., PBPN v. Jim; No. CR 2007-12-63, (citing the defendant for conspiracy to commit attempted homicide in the first degree, Potawatomi Law \& Order Code section 15-2-11(A); 15-31 (A) and 15-3-2(A); conspiracy to commit assault in the first degree, section 15-2-1(A) and 15-32(A); conspiracy to commit assault in the first degree, section 15-2-1(A) and 15-3-2(A); conspiracy to commit assault in the second degree, section 15-2-2(A) and 15-3-2(A); and burglary section 15-110(A)) (PBPN Dist. Ct. May 2008).
} 


\section{B. Unintended Consequences-Multiple Prosecutions}

Evolution of language in the first draft of the Kansas Act in 1938 to its final enacted form dramatically changed the effect of the law. The first version sought to transfer authority to prosecute offenses committed by Indians in Indian country from the federal government to state authority. ${ }^{143}$ Had that draft become law, the U.S. Attorney could no longer have prosecuted crimes occurring on reservations in Kansas. However, as passed, the Kansas Act extends, rather than transfers, authority to prosecute to the state, while at the same time retaining within the federal authority the ability to prosecute offenses under federal law. As such, a single action constituting a crime under state law and federal law may be prosecuted by both entities. Doing so does not constitute double jeopardy because state government and federal government are separate sovereigns. ${ }^{144}$ Similarly, a single act constituting an offense under a tribal criminal code and federal law is subject to prosecution by both sovereigns. ${ }^{145}$ While this was not contemplated as an issue when the Kansas Act was conceived, as discussed above, the establishment of tribal courts in all four Native nations in Kansas makes this more than just a theoretical possibility. Even less theoretical are circumstances in which a single act constitutes a crime under tribal law and state law. Since tribal nations and the state of Kansas are each sovereign entities, dual prosecutions under state and tribal law do not constitute double jeopardy either. ${ }^{146}$

It is even conceivable that one single act could constitute violation of tribal law, state law, and federal law. If so, a Native person could face triple prosecution. This framework of three separate sovereigns having criminal jurisdiction in one location makes members of federally

143. H.R. 9757, 75th Cong. (3d Sess. 1938); see supra Part III.B.1.

144. See generally Bartkus v. Illinois, 359 U.S. 121, 138-39 (1959) (describing precedent permitting successive prosecution "by a government other than the one first prosecuting"); Abbate v. United States, 359 U.S. 187 (1959) (holding that federal prosecution does not prohibit subsequent state prosecution of an individual for the same acts, nor does state prosecution bar a subsequent federal one). However, the U.S. Department of Justice, under what is referred to as the "Petite Policy," discourages federal prosecutors from filing federal charges in cases in which prosecution by state authorities will adequately address the wrong committed by the single offense. U.S. DEP'T JUSTiCE, United StATES AtTORneys' MANUAL § 9-2.031 (1997), available at http://www.justice. gov/usao/eousa/foia_reading_room/usam/title9/2mcrm.htm\#9-2.031. The Petite Policy derives its name from Petite v. United States, 361 U.S. 529 (1960).

145. United States v. Wheeler, 435 U.S. 313, 329-30 (1978), superseded by statute on other grounds, Indian Civil Rights Act, 25 U.S.C. §§ 1301-1303 (2006).

146. Although Kansas courts have not directly taken up this issue, there is no reason to believe the analysis and result would be different in this circumstance than it was in Wheeler. Id. 
recognized tribes unique in that they alone face the possibility of triple prosecution for a single act. ${ }^{147}$ While the authors of this Article are not aware of any instance in which a person faced triple prosecution for a single act, the possibility exists under the law.

More immediate is the risk that, under the Kansas Act, a Native person will be the subject of tribal and state prosecutions for an act that that occurs on Indian lands in Kansas. Statistics on the frequency of dual prosecutions are not readily available, ${ }^{148}$ however, there is ample anecdotal evidence that this is not a mere theoretical possibility. For example, the Washburn Law Clinic served as counsel for a Native American client charged with offenses under a tribal criminal code. ${ }^{149}$ While facing charges in tribal court, the client also faced charges for the same act in state court. Initially, the tribal prosecutor on the case indicated he would consult with the state prosecutor to see if the state would consider deferring prosecution to tribal authorities. The tribal prosecutor stated that if he could not dissuade state authorities, he would probably not pursue charges in tribal court. But when attempts to get the state to decline prosecution failed, the tribal prosecutor felt the charges were serious enough and affected the fabric of the community such that the tribe needed to be involved in seeking justice. He ultimately initiated prosecution in tribal court. When both prosecutions had concluded, the client stood convicted of a felony in state court and offenses in tribal court. Indeed, had the federal government chosen to step in, the accusations would have qualified for prosecution under the federal Major Crimes Act, resulting in a triple prosecution. This example is not the only instance of dual prosecutions occurring due to the Kansas Act.

Native people in Kansas have expressed surprise and concern that a single act on a reservation can result in multiple prosecutions. ${ }^{150}$ Recently, some tribal and state prosecutors have addressed that concern by taking steps to prevent dual prosecutions. For example, there is a

147. But see Duma, supra note 38 (arguing that since the state of Kansas is granted jurisdiction on Indian lands by the federal government under the Kansas Act, dual prosecution by federal and state governments for a single act on a reservation would violate double jeopardy prohibitions because the authority to prosecute for both sovereigns originates from the federal government).

148. Attempts to obtain statistics from tribal courts and state courts regarding the incidence of dual prosecutions were unsuccessful.

149. To protect privacy of the Clinic client, details about the charges and the courts in which the offenses were filed are omitted from this discussion. This information comes from a case supervised by co-author John Francis, Professor of Law and Director of Law Clinic at Washburn University School of Law.

150. This sentiment has been expressed to members of Washburn University Law Clinic working with co-authors Professors John Francis and Aliza Organick. 
memorandum of agreement between Prairie Band Potawatomi Nation and the Jackson County prosecutor that they will avoid having both entities prosecute Native people for a single act. ${ }^{151}$ While this agreement is effective relief from the risk of dual prosecutions, it is only a band-aid fix to the problem. A change in policy or philosophy by administrators of either entity could end the agreement, restoring the risk of multiple prosecutions

\section{Sentencing Implications}

As previously discussed, there are a host of issues that arise when a person faces prosecution for the same behavior both in tribal court and in state court, as is the case with the Kansas Act. These double, and potentially triple, prosecutions have sentencing ramifications on the state and federal levels. ${ }^{152}$ Kansas state sentencing laws clearly allow for tribal convictions to contribute to an offender's criminal history. ${ }^{153}$ Federal jurisdiction also adds to this patchwork of prosecutions, making members of federally recognized Tribal Nations particularly vulnerable to enhanced federal penalties. ${ }^{154}$

As recently as 2004, in the case United States v. Lara, the U.S. Supreme Court ruled that "the Double Jeopardy Clause does not prohibit the Federal Government from proceeding with the present prosecution for a discrete federal offense.”155 In that case, defendant Billy Jo Lara, an enrolled member of the Turtle Mountain Band of Chippewa Indians,

151. Memorandum of Agreement Between the Jackson County Attorney and the Prairie Band Potawatomi Nation District Court Prosecutor (Nov. 3, 2009) (on file with law review). The Memorandum includes, among other cooperative provisions, the following provision:

Consultation. The parties are working openly and cooperatively with each other with the goal and intent to provide the County and the Nation the mutual benefit of ensuring that their respective communities are fully and sufficiently protected by law enforcement and that the criminal offender is duly prosecuted in one jurisdiction. In the effort to avoid the potential situation where a PBPN tribal member may be subject to a criminal prosecution in three jurisdictions (Tribal, State, and Federal.), the parties will consult with each other to efficiently utilize their respective resources while at the same time ensuring that proper criminal prosecution occurs in an appropriate jurisdiction. Id.

152. Kevin K. Washburn, Tribal Courts and Federal Sentencing, 36 ARIz. ST. L.J. 403, 406 (2004).

153. See Kan. StAT. ANN. § 21-4711(e) (2007) (repealed 2010). A new sentencing statute, KAN. STAT. ANN. 21-6811(e), will become effective in July 2011.

154. Barbara L. Creel, Tribal Court Convictions and the Federal Sentencing Guidelines: Respect for Tribal Courts and Tribal People in Federal Court Sentencing, 46 U.S.F. L. REV. (forthcoming 2011).

155. United States v. Lara, 541 U.S. 193, 210 (2004). 
lived with his children and his wife, a member of the Spirit Lake Sioux Tribe, on the Spirit Lake Reservation in North Dakota. ${ }^{156}$ Following an altercation with a federal officer on the Spirit Lake Reservation, Lara was prosecuted and convicted in Spirit Lake Tribal Court for “"violence to a policeman.",157 Lara was subsequently charged with assaulting a federal officer in the Federal District Court for the District of North Dakota. ${ }^{158}$ The Supreme Court recognized the federal prosecution would normally have raised double jeopardy problems because the "[k]ey elements of [the] federal crime mirror[ed] elements of the tribal crime of 'violence to a policeman.",159 However, the Court reasoned that Lara's double jeopardy claim depended on whether the Tribe's power to punish nonmember Indian offenders was based on "inherent tribal sovereignty" or "delegated federal authority." 160 Therefore, the Court had to consider the constitutionality of 25 U.S.C. § 1301(2), through which Congress sought to "enlarg[e] the tribes' own 'powers of self-government' to include 'the inherent power of Indian tribes, hereby recognized and affirmed, to exercise criminal jurisdiction over all Indians,' including nonmembers."

In determining the constitutionality of 25 U.S.C. $\S 1301(2)$ and, consequently, the source of a tribe's jurisdiction over "nonmember Indians," the Supreme Court discussed the fluctuating history of Federal Indian Policy, recounting Congress's move from removal, to assimilation and the break-up of tribal lands, to termination, and then to selfdetermination. ${ }^{162}$ This continual change in policy led the Court to conclude that there is a great need for the Constitution to be interpreted to authorize Congress "to enact legislation that both restricts and, in turn, relaxes those restrictions on tribal sovereign authority." "Th3 Therefore, the Court resolved that, in the case of 25 U.S.C. § 1301(2), Congress's decision to "rela[x] restrictions on the bounds of the inherent tribal authority that the United States recognizes" is constitutionally permissible. ${ }^{164}$ The Court dismissed the additional due process and equal

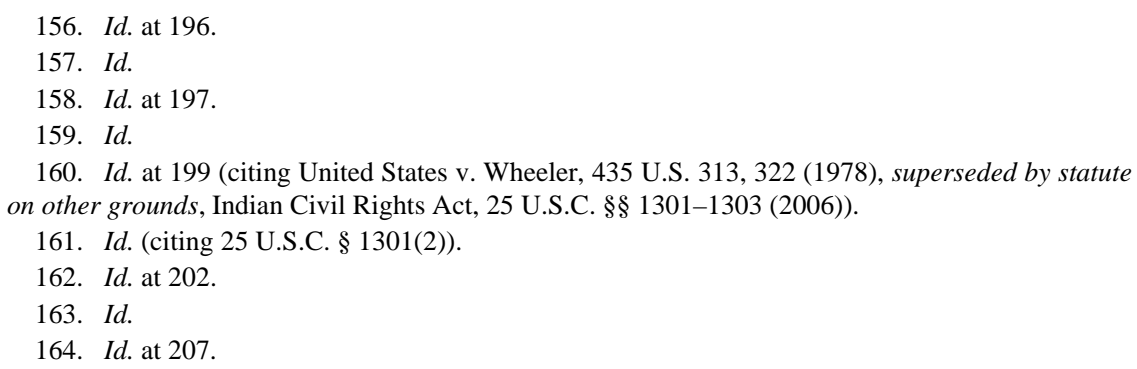


protection claims raised by Lara and ultimately decided that the Constitution allows Congress to authorize tribes to prosecute nonmember Indians as a matter of the tribe's inherent authority. ${ }^{165}$ As such, in prosecuting Lara, the Spirit Lake Tribe was acting as a distinct sovereign, and thus the Double Jeopardy Clause did not prohibit subsequent federal prosecution for the separate federal offense. ${ }^{166}$

This case means that offenders who are members of a federally recognized tribe could conceivably be prosecuted in a tribal, state, and federal court for the same behavior, while a non-Indian would only be subject to state and federal jurisdiction. ${ }^{167}$ Certainly, there is an argument to be made for showing respect for tribal court convictions by giving them the same weight in federal sentencing that state court convictions enjoy. ${ }^{168}$ However, this desire is in tension with the current system that potentially has a disproportionate sentencing impact on members of Indian Tribes and Nations. ${ }^{169}$

Given the increased likelihood of members of Indian Tribes and Nations to be subject to prosecution by tribal, state, and federal authorities, "Native Americans who come into contact with the criminal justice system are more likely to be charged, and sentenced, under federal law than the average American."170 Therefore, the federal sentencing implications are particularly important when discussing this group of offenders. There are several ways in which prior tribal prosecutions can figure into federal sentencing, from statements made in tribal court proceedings to the fact that convictions and sentences were imposed in tribal court. In the Tenth Circuit case United States $v$. Denetclaw, the court upheld the use of a defendant's tribal court pleas to impeach his testimony at the federal trial arising from the same assault incidents. ${ }^{171}$ The circuit court then affirmed the sentencing district court's use of that perjurious testimony to enhance the defendant's sentence based on obstruction of justice. ${ }^{172}$ Additionally, sentences for

\footnotetext{
165. Id. at 209-10.

166. Id. at 210 .

167. "Indian" is used to describe those persons who would be subject to the jurisdiction of the United States as an Indian under 18 U.S.C. § 1153. 25 U.S.C. § 1301(4) (2006).

168. See Washburn, supra note 152, at 406 (proposing reforms for the treatment of tribal court proceedings in federal sentencing determinations in order to "ensure that tribal court adjudications and sentences are accorded whatever respect they are due").

169. Creel, supra note 154.

170. United States v. Bad Marriage, 392 F.3d 1103, 1115 (9th Cir. 2004).

171. 96 F.3d 454, 457-58 (10th Cir. 1996).

172. Id. at 458-59.
} 
federal convictions can be greatly affected by just the fact that previous tribal and state sentences exist-whether those previous convictions were based on the same behavior as the federal offense or on completely different offenses that occurred years earlier. ${ }^{173}$

Although the Federal Sentencing Guidelines exclude certain types of sentences from counting as prior sentences, a host of tribal, state, and federal adjudications can enhance an offender's criminal history score. ${ }^{174}$ The Federal Sentencing Guidelines have been advisory since 2005; however, federal district judges must still calculate and consider the applicable Guidelines range when sentencing an offender. ${ }^{175}$ The Guidelines contain several factors relevant to an offender's proper sentence, including criminal history, as well as specifics about the offense, which all correlate to points that are ultimately used to find a sentencing range on a grid. In determining an offender's criminal history, section 4A1.1 of the Guidelines calls for a sentencing court to add a certain amount of points to an offender's criminal history calculation based on the length of prior sentences imposed, including state sentences. ${ }^{176}$ Although section 4A1.2(i) of the Guidelines explains that sentences resulting from tribal court convictions are not counted in criminal history calculations, ${ }^{177}$ section 4A1.3(a)(1) provides for tribal court convictions to be considered when a defendant's calculated criminal history "substantially under-represents the seriousness of the

173. However, the Federal Sentencing Guidelines do not count prior convictions for which a sentence was imposed more than ten years prior to the defendant's commencement of the instant federal offense. U.S. SENTENCING GUIDELINES MANUAL § 4A1.1(c) cmt. (2010).

174. Id. § 4A1.2(c) (explaining which sentences are counted and excluded).

175. In 2005, the Supreme Court decided United States v. Booker, in which it rendered the Guidelines advisory and directed circuit courts to review sentences for "unreasonableness." 543 U.S. 220 (2005). In Booker and several follow-up cases, the Court explained that, in fashioning a reasonable sentence, a district judge must properly calculate the applicable Guidelines range and then tailor a sentence that satisfies the sentencing factors set forth in 18 U.S.C. § 3553(a). Id. at 259-60; see also Gall v. United States, 552 U.S. 38, 49-50 (2005) (stating that the district judge should consider all of the section 3553(a) factors). Section 3553(a) sentencing factors include the following: (1) the kinds of sentence and the sentencing range established for the applicable category of offense committed by the applicable category of defendant as set forth in the guidelines; (2) any pertinent policy statement issued by the Sentencing Commission; (3) the need to avoid unwarranted sentencing disparities; (4) the need to provide restitution to victims; and (5) the requirement to impose sentences that reflect the seriousness of the offense, promote respect for the law, provide just punishment, afford adequate deterrence, protect the public, and effectively provide the defendant with needed educational or vocational training and medical care. 18 U.S.C. § 3553(a).

176. For instance, section 4A1.1 directs sentencing courts to "[a]dd 3 points for each prior sentence of imprisonment exceeding one year and one month" and to "[a]dd 2 points for each prior sentence of imprisonment of at least sixty days,” etc. U.S. SENTENCING GUIDELINES MANUAL § 4A1.1.

177. Id. § 4A1.2(i). 
defendant's criminal history or the likelihood that the defendant will commit other crimes." ${ }^{178}$ In fact, it is not unusual for tribal convictions to be considered in this manner.

Several Eighth Circuit cases illustrate the use of prior tribal court convictions in federal sentencing determinations. In the 2004 Eighth Circuit case of United States v. Harlan, Terry Harlan had been convicted of assault with a dangerous weapon for an incident occurring on the Omaha Indian Reservation. ${ }^{179}$ The district court determined that the Guidelines did not adequately capture the defendant's criminal history, and therefore the court increased the applicable criminal history based in part on Harlan's prior tribal court convictions. ${ }^{180}$ This augmented Harlan's criminal history category from I to III, which increased the initial Guidelines range of fifty-one to sixty-three months imprisonment to a range of sixty-three to seventy-eight months. ${ }^{181}$ Ultimately, Harlan was sentenced to seventy-two months of imprisonment, nine months longer than what would have been applicable under the then-mandatory Guidelines had criminal history category I been applied. ${ }^{182}$ On appeal, the Eight Circuit relied on section 4A1.3(a) in upholding the sentence determination and explained that "the sentencing court should be guided, at least in part, by the criminal history category which would have applied had the uncounted prior convictions been computed." 183 Similarly, in United States v. Sitting Bear, the Eight Circuit upheld the consideration of prior tribal convictions. ${ }^{184}$ In that case, parents Sitting Bear and Marshall were convicted of second degree murder and aiding and abetting second degree murder, respectively, for the beating death of their four-year-old son. ${ }^{185}$ The circuit court found it reasonable for the district court to have considered Marshall's prior child neglect convictions in tribal court in determining her ultimate sentence for the federal offense. ${ }^{186}$ What is interesting about Sitting Bear is that the sentences for the defendants were imposed after the Supreme Court demoted the Guidelines to advisory status in United States v. Booker. ${ }^{187}$

\footnotetext{
178. Id. § $4 \mathrm{~A} 1.3(\mathrm{a})(1)$.

179. 368 F.3d 870 (8th Cir. 2004).

180. Id. at 872,874

181. Id. at 873 .

182. Id.

183. Id. at 874-75.

184. 436 F.3d 929 (8th Cir. 2006).

185. Id. at 931-32.

186. Id. at 932, 936

187. See 543 U.S. 220, 266 (2005).
} 
Therefore, although the sentencing court was required to calculate and determine the applicable Guidelines range, which was 151 to 188 months of imprisonment in Marshall's case, ${ }^{188}$ the sentencing court was free to depart from the range if it found that a Guidelines sentence would not satisfy the factors set forth in 18 U.S.C. $\S 3553(a) .{ }^{189}$ Once the sentencing court in Sitting Bear decided that the Guidelines range would not provide adequate punishment considering Marshall's prior abusive behavior, the court did not have to determine a numerical value to place on the prior tribal convictions being incorporated into the criminal history category, as the sentencing court had to do in Harlan. Instead, the court was free to fashion a sentence that it determined reflected the section 3553(a) sentencing factors, without indicating how much weight it was putting on those prior tribal convictions. ${ }^{190}$ In Marshall's case, the court determined that a sentence of 228 months adequately reflected the severity of her offense and criminal history. ${ }^{191}$ Apparently, post-Booker, sentencing courts have much more latitude in how much emphasis they may put on prior tribal convictions.

Of course, one could argue that this tribal conviction penalty only applies to prior tribal convictions that are unrelated to the instant federal offense for which a defendant is being sentenced. The term "prior sentence" is defined by the Guidelines as "any sentence previously imposed upon adjudication of guilt, whether by guilty plea, trial, or plea of nolo contendere, for conduct not part of the instant offense."192 Therefore, behavior that constitutes the bases for both a prior state or tribal sentence and the instant federal sentencing should not be double (or triple) counted as a prior sentence for criminal history purposes. However, circuit courts have disagreed on how to decipher when they will not consider conduct punished by another jurisdiction as part of the instant federal offense. For instance, the Tenth Circuit has affirmed the use of a defendant's state sentence based on aiding and abetting a methamphetamine manufacturing operation as a prior conviction in the federal sentencing for being a felon in possession of a firearm, even though the firearm was found when the defendant was arrested for the state offense. ${ }^{193}$ By contrast, the Third Circuit has explicitly rejected the

\footnotetext{
188. Sitting Bear, 436 F.3d at 932.

189. See Booker, 543 U.S. at 266.

190. See Sitting Bear, 436 F.3d at 936.

191. Id. at 932 .

192. U.S. SENTENCING GUIDELINES MANuAL § 4A1.2(a)(1) (2010).

193. United States v. Browning, 252 F.3d 1153, 1158-59 (10th Cir. 2001).
} 
severability test employed by the Tenth Circuit and has instead remanded a case for resentencing where a defendant's criminal history was increased based on a state involuntary manslaughter sentence using a gun that was the basis of the instant federal sentencing for being a felon in possession of a firearm. ${ }^{194}$ Therefore, it is quite conceivable that conduct that leads to prosecution by tribal, state, and federal authorities may result in an enhanced criminal history score for federal sentencing purposes. And in the current advisory Guidelines, it is impossible to know how much of an impact those prior offenses will have on a federal sentencing determination. Consequently, the Kansas Act opens the door for serious sentencing consequences for offenders who are Indian and subject to tribal, state, and federal concurrent jurisdiction.

\section{Practical Consequences of the Act}

At present, all four tribes within the state of Kansas operate a tribal court system exercising both civil and criminal jurisdiction. ${ }^{195}$ The largest of the four, the Prairie Band Potawatomi Tribe, maintains a judiciary consisting of a district court judge, two associate district court judges, a special district court judge, three court of appeals justices, a separate employment dispute tribunal, a healing to wellness court, and a peacemaker's circle for alternative dispute resolution. ${ }^{196}$ The annual judicial budget is $\$ 237,848$. ${ }^{197}$ The tribe hires a prosecutor and four public defenders on a contract basis. ${ }^{198}$ All judges, prosecutors, and public defenders are law-trained members of state bar associations, predominately the Kansas Bar. ${ }^{199}$ The tribe also maintains a police

194. United States v. Irvin, 369 F.3d 284, 290 (3d Cir. 2004).

195. Tribal Court, IOWA TRIBE, http://iowanation.org/home/government/tribal-court (last visited June 3, 2011); Kickapoo District Court, KAN. KICKAPOO TRIBE, http://www.ktik-nsn.gov/ nation_tribal_district_court.htm (last visited June 3, 2011); Judicial Council, PRAIRIE BAND POTAWATOMI NATION, http://www.pbpindiantribe.com/judicial-council.aspx (last visited June 3, 2011); Judicial, SAC \& FOX NATION, http://www.sacandfoxnation-nsn.gov/government/judicial/ (last visited June 3, 2011).

196. Judicial Council of the Prairie Band Potawatomi Nation Dispute Resolution System, PRAIRIE BAND POTAWATOMI NATION, http://www.pbpindiantribe.com/judicial-council.aspx (last visited Apr. 13, 2011).

197. E-mail from Royetta Rodewald, Judicial Admin. for the Prairie Band Potawatomi Tribe, to co-author, Stacy Leeds (June 2, 2011) (on file with law review).

198. Id.

199. See Judicial Council of the Prairie Band Potawatomi Nation Dispute Resolution System, PRAIRIE BAND POTAWATOMI NATION, http://www.pbpindiantribe.com/judicial-council.aspx (last visited Apr. 13, 2011). 
force. $^{200}$ The Potawatomi Reservation consists of 77,400 acres within Jackson County, Kansas. ${ }^{201}$

The tribal court may exercise jurisdiction over individual Indians when the crime occurs within the reservation boundary and the substantive law is defined by tribal legislation. ${ }^{202}$ The state court may exercise jurisdiction over the same individual, with the substantive law defined by state legislation. ${ }^{203}$ The federal court may exercise jurisdiction over the same individual, with the substantive law defined by federal legislation. ${ }^{204}$

For example, assume a robbery takes place on the reservation. The assailant and victim are both tribal members-citizens of the Prairie Band Potawatomi. Law enforcement officers, both tribal and state police dispatches, are alerted to the activity when the victim phones 911 emergency services. Both tribal and state police officers arrive at the scene to begin their independent investigations. Two days later, the assailant is arrested by tribal police and taken from his home, on the reservation, to the Jackson County Jail, where the tribe pays contract fees to Jackson County to house the suspect pending arraignment because the tribe does not maintain a tribal detention facility.

The tribal prosecutor files charges in tribal district court under section 15-2-41 of the Prairie Band Potawatomi Code. ${ }^{205}$ The county prosecutor files charges in state district court under section 21-5420 of the Kansas Statutes. ${ }^{206}$ Although unlikely, the U.S. attorney has the

200. Prairie Band Potawatomi Nation Organizational Chart, Prairie Band Potawatomi NATION http://www.pbpindiantribe.com/upload/pdf/PBP\%20Organizational\%20Chart.pdf (last visited Apr. 13, 2011).

201. A Vision of Accomplishment: Summary of the Potawatomi Nation's Journey to Gaming, PRAIRIE BAND POTAWATOMI NATION, http://www.pbpindiantribe.com/vision-of-accomplish ment.aspx (last visited Apr. 13, 2011).

202. This type of inherent tribal criminal jurisdiction was recognized in Ex Parte Crow Dog, 109 U.S. 556 (1883) and has remained a well-recognized retained tribal power. Congress has statutorily recognized this inherent tribal power to prosecute all Indians, without regard to specific tribal membership, citizenship or enrollment, in the Indian Civil Rights Act, 25 U.S.C. § 1302(2); see also Diepenbrock v. Merkel, 97 P.3d 1063, 1065 (Kan. Ct. App. 2004) (citing Okla. Tax Comm'n v. Potawatomi Tribe, 498 U.S. 505, 509 (1991)).

203. The Kansas Act provides for state prosecution of crimes on Indian reservations within the state of Kansas without divesting the tribes of tribal inherent authority as described supra note 203. 18 U.S.C. § 3243 (2006); see also State v. Oyler, 803 P.2d 581, 583 (Kan. Ct. App. 1990).

204. Major Crimes Act, 18 U.S.C. § 1153; General Crimes Act, 18 U.S.C. § 1152

205. See PotaWATOMI LAW \& ORder Code § 15-2-41 (2010).

206. See KAn. STAT. ANN. § 21-5420 (West 2007). 
authority to file charges in federal district court under section 1153(a) of the Major Crimes Act. ${ }^{207}$

In each court, the defendant, if unable to afford an attorney, will receive court appointed counsel. In each court, the defendant is entitled to a jury trial upon request. Each court is empowered to impose a sentence upon conviction. Even if only two jurisdictions, tribal and state, actively pursue prosecution, as a practical reality, economic and judicial efficiency and fundamental fairness questions abound. Is this necessary to address lawless on the reservation? If there once was a climate of lawlessness on the reservations, has that climate been eliminated by the presence of tribal police forces and tribal courts? This is particularly true in times of economic hardships for state and tribal governments as well as budget uncertainty on the federal level. The state of Kansas has instituted mandatory furloughs for state courts and judicial resources have been severely reduced. ${ }^{208}$

\section{PROPOSAL FOR LEgisLATIVE AND OTHER REFORM}

As it currently stands, the state of Kansas and the tribes within the state are expending scarce financial resources to duplicate prosecution of Indian country crimes. In addition to employing their own police forces and judicial staff to respond to criminal activity, the tribes and state routinely detain and convict the same defendant for a single criminal offense. Meanwhile, the federal government plays little or no role. Although the passage of the Kansas Act responded to a perception of lawlessness and a lack of tribal court systems in 1940, the practical realities, seventy years later, no longer require the state to have jurisdiction that intrudes into Indian country in Kansas.

This Article poses three possible solutions to remedy the current inefficiencies in the system. First, the authors advocate for a full repeal of the Kansas Act and call upon Congress to restore the same federaltribal criminal jurisdiction model that exists in other states. Second, in the absence of a full repeal, consideration of partial repeal should be explored. Finally, should the Kansas Act remain the law, the tribes and state should consider meaningful cooperative agreements between sovereigns in order to avoid duplicative prosecution and unnecessary expenditure of scarce resources.

\footnotetext{
207. See 18 U.S.C. § 1153(a).

208. See Kansas Courts Begin Friday Furloughs, WIBW.com (Apr. 9, 2010), http://www.wibw. com/localnews/headlines/90426729.html.
} 


\section{A. Full Repeal of the Kansas Act}

The Kansas Act should be fully repealed because circumstances no longer necessitate the expenditure of state money for prosecutions that are adequately handled by tribal or federal officials. Changes brought by the Tribal Law and Order Act of 2010 render a tribal-federal jurisdictional framework more practical than the multiple jurisdictional overlap created by the Kansas Act.

Under this model, the U.S. Attorney within the state of Kansas will prosecute Indian country crimes pursuant to the Major Crimes Act and General Crimes Act. At present, federal courts are not hearing Indian country criminal cases in Kansas and the U.S Attorneys' office is not yet exercising its full authority under the Tribal Law and Order Act of 2010 to prosecute major crimes and interracial crimes occurring in Indian country.

There are no reported federal cases from Kansas and having spoken to tribal prosecutors within the state, the authors are unaware of a single federal charge being brought in the last decade, despite congressional authorization to do so. Under the Tribal Law and Order Act of 2010, the duties of the U.S. attorneys to actively prosecute Indian country crimes are now highlighted and prioritized. In fact, an Indian country liaison has been appointed in the U.S. Attorneys' Office to fulfill this obligation. Federal authorities in Kansas should no longer rely on the state to carry out its responsibilities in this arena. In this economic climate, with Kansas state courts subject to mandatory court furlough days and other cutbacks, there is no reasonable incentive for the state to continue prosecutions that can be pursued by tribal or federal authorities.

The tribe should assess to what extent, if any, the U.S. Attorney should be engaged to prosecute certain crimes. The Kansas Act creates a situation unique to Kansas by leaving intact inherent tribal jurisdiction, granting jurisdiction to the state but expressly preserving federal jurisdiction over Indian country crimes. There might be times, given investigative and prosecutorial resources, that both the tribe and state would advocate full federal engagement. To date, federal prosecutions have been virtually nonexistent on Indian reservations Kansas, likely due to the fact that the state has traditionally prosecuted coupled with the increased criminal dockets in tribal courts. With the recent passage of the Tribal Law and Order Act of 2010, which prioritizes federal-tribal communication of decisions to prosecute or decline prosecution, the time is ripe for discussion. The model suggested here recognizes that the increased jurisdictional reach of tribal courts makes them capable of handling many prosecutions previously pursued by state authorities. 
Federal prosecutions contemplated by the Tribal Law and Order Act of 2010 can fill the gap in those circumstances in which limitations imposed upon tribal courts will not fully meet the interests of Native communities. This suggestion is made contemplating that the U.S. Attorneys' Office will continue to decline prosecution when charges by another entity will adequately address the wrong committed by an offense. ${ }^{209}$ If so, tribal sovereignty regarding criminal prosecutions will be increased rather than diminished. There may be occasions, however, when a tribe might decline the exercise of prosecutorial powers in favor of federal prosecution. On those occasions, federal authorities are required to step in when the offense involved falls under federal jurisdiction. Even on occasions when a tribe pursues prosecution, federal law enforcement agencies should stand ready to lend their expertise and resources to support tribal prosecutions.

\section{B. Partial Repeal of the Kansas Act}

There are two possible partial repeal options, neither of which creates a jurisdictional void in prosecutions. First, the Kansas Act could be repealed on a tribe-by-tribe basis. Meaningful communication and consultation with tribal nations in Kansas should take place to determine whether each tribe opposes or acquiesces to continued state jurisdiction over crimes within the specific reservation. ${ }^{210}$ Recall that the Prairie Band Potawatomi Nation, the state's largest native population, never consented to, and in fact actively opposed, the extension of state jurisdiction onto the reservation. ${ }^{211}$

Public Law 280, another federal act that provides for limited state jurisdiction over reservations in other states, provides a mechanism for retrocession of jurisdiction to the tribes upon consent of the impacted state. This model has worked well to effectuate a return of exclusive

209. See supra note 144 for discussion of the U.S. Attorneys' "Petite Policy."

210. For instance, the Kansas Act could be repealed as to Prairie Band Potawatomi Nation, a tribe that opposed and continues to oppose the Act. In that instance, Jackson County, Kansas would no longer prosecute Indians that commit crimes on that particular reservation. In contrast, however, it might be that another tribe is comfortable with continued state jurisdiction pursuant to a Memorandum of Understanding between the state and tribal prosecutors, and the Kansas Act would remain effective for that reservation, with the practical consequences of continued state jurisdiction worked out on the ground on a case by case basis.

211. It may very well be the case that some tribes would support continued state involvement. However, a one-size-fits-all approach in which tribal interests are deemed to be homogenous between different reservations was inappropriate in the 1940s when the Kansas Act was passed and continues to be inappropriate in the current political climate. 
tribal jurisdiction over some matters. The return of exclusive jurisdiction to the tribes in the Kansas example may easily emulate the Public Law 280 retrocession provisions.

Second, the Kansas Act could be repealed in that non-Indian defendants who commit a crime in Indian country continue to be prosecuted in state court ${ }^{212}$ while Indian defendants who commit a crime within Indian country are prosecuted in tribal court. In both instances, the federal government retains the power to prosecute under the Major Crimes Act or the General Crimes Act, leaving intact U.S. attorneys' role as statutorily mandated.

\section{Tribal-State Cooperative Agreements}

Increasingly, tribes and states are entering into cooperative agreements between sovereigns to accomplish a number of mutually beneficial solutions to practical problems. ${ }^{213}$ These agreements address judicial full faith credit concerns, regulatory matters such as foster home licensing, and sharing of resources for infrastructural needs such as road construction and utility access. Cross-jurisdictional law enforcement issues have also been addressed through these types of agreements. The key to their success is that the agreements are entered into on a sovereign-to-sovereign capacity that outlive political appointments or election cycles.

If the Kansas Act is neither repealed nor amended, the authors encourage communication and the consideration of intergovernmental agreements. First, tribes and states may consider agreements such as the recent Memorandum of Agreement (MOA) between the Jackson County Attorney and the Prairie Band Potawatomi Tribal Prosecutor. Under this MOA, the county attorney and the tribal prosecutor agree to work in a cooperative manner to minimize dual prosecutions of a single defendant. ${ }^{214}$ The MOA has resulted in better communications between the two prosecutors and operates on the principle of good faith prosecutorial discretion. With such communication, the relative jurisdictions are somewhat better equipped to make decisions that will

212. Because tribal courts lack criminal jurisdiction over non-Indians, prosecution of nonIndians by the state poses no additional threat to tribal self-governance nor does it create state-tribal dual-prosecution scenarios as described in this Article.

213. Symposium, Emerging Models of Tribal and State Cooperative Agreements, 47 TULSA L. REV. (forthcoming Spring 2012).

214. Memorandum, supra note 151. 
positively impact court dockets, financial resources devoted to prosecution and indigent defense systems, and avoid unnecessary duplication.

Although a step in the rights direction, an MOA between individual prosecutors only temporarily addresses the issue and provides a band-aid to a much bigger problem and is subject to personnel and political changes. As such, it is not a reliable shield against dual prosecutions and leaves defendants vulnerable to multiple convictions that could have heightened consequences in sentencing on both the state and federal level. The authors advocate that future MOAs have language upon which a defendant can rely on as a bar to subsequent dual prosecution in a single case. Also, the authors advocate that future MOAs be entered into by the relative sovereigns, rather than by individuals.

\section{CONCLUSION}

The Kansas Act is no longer relevant. When the legislation was passed in 1940 amidst of narrative of perceived lawlessness on Kansas Indian reservations, Congress presumed that tribal governments would no longer exist and that tribal people would become fully assimilated as state citizens without tribal affiliation. On this premise, the door was opened for a transition to full state authority; however, the transition was never fully realized. In fact, the Kansas Act expressly preserves a federal role in prosecuting Indian country crimes and subsequent federal Indian policy ultimately revived tribal governments and supports tribal selfdetermination. To that end, all tribes in Kansas maintain an active tribal court system with appellate review. As such, the need for the state to shoulder responsibility, both financially and logistically, should be critically reexamined.

Even though no tribal courts existed at the time of enactment, tribal objections to state authority within the reservation boundaries is welldocumented and the perceived jurisdictional gaps were disingenuous given federal statutory authority to prosecute Indian defendants for major crimes and non-Indian defendants for interracial crimes. Further, the state was previously recognized as having authority to prosecute crimes committed in Indian country where the perpetrator and victim were nonIndians. The only actual jurisdiction gap that existed was the prosecution of minor crimes committed by an Indian against another Indian, all matters that are surely within the purview of the modern tribal courts that currently exist.

In addition to the present day relevancy, continuing dual prosecutions by the state and tribes is equally without merit. Currently, 
the Prairie Band Potawatomi Nation tribal courts are fully functioning with a $\$ 237,848$ annual tribal appropriated budget which includes a three judge court of appeals, a district court judge, two associate district court judges, a special district court judges, a healing to wellness court, a peacemaker tribunal, an employee appeals tribunal, a probation department, a court administrator and three support staff. ${ }^{215}$ The budget includes funds for contracts with five public defenders and two additional court appointed attorneys, in addition to the pro bono legal services of Washburn Law Clinic. ${ }^{216}$ The tribal court is well-equipped to provide adequate services to its population to the same extent as Kansas county courts. This is particularly true in light of recent cutbacks at the state level.

Nonetheless, the Kansas Act continues to operate on the false assumption that tribes are not equipped to meet the prosecutorial needs of their jurisdiction. At a time when the Kansas state judicial budget is strained, the jurisdictional reach of tribal courts has expanded, and the four tribal nations in Kansas have demonstrated they are capable of administering justice within their borders, there is no reason for the Kansas Act to continue to undercut tribal sovereignty.

215. See supra Part IV.D.

216. See supra Part IV.D. 